\title{
SYNTHESIS AND ANTIMICROBIAL ACTIVITY OF NEW SUBSTITUTED DIHYDROPYRIMIDINE DERIVATIVES
}

\author{
Mostafa A. Hussein ${ }^{1 *}$, Samia G. Abdel Moty ${ }^{1}$, Salah A. Abdel Aziz ${ }^{2}$ and Mahrous A. Abou- \\ Salim $^{3}$ \\ ${ }^{1}$ Department of Pharmaceutical Organic Chemistry, Faculty of Pharmacy, Assiut University, \\ Egypt \\ ${ }^{2}$ Department of Pharmaceutical Medicinal Chemistry, Faculty of Pharmacy, Al Azhar \\ University, Assiut, Egypt \\ ${ }^{3}$ Department of Pharmaceutical Organic Chemistry, Faculty of Pharmacy, Al Azhar \\ University, Assiut, Egypt
}

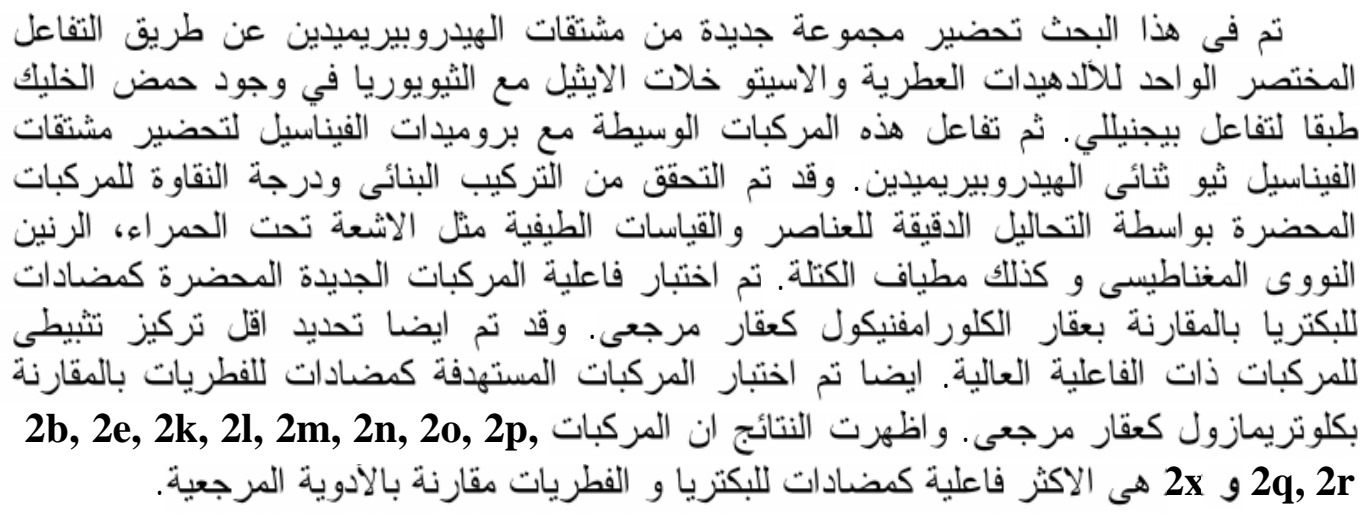

A new series of ethyl 6-methyl-4-(substituted)phenyl-2-(substituted)-phenacyl-thio-1,4dihydropyrimidine-5-carboxylate (2a-x) was prepared by reaction of ethyl 1,2,3,4-tetrahydro-6methyl-4-(substituted)phenyl-2-thioxopyrimidine-5-carboxy-late $\mathbf{1}(\boldsymbol{a}-\boldsymbol{d})$ with phenacyl bromides. Compounds $\mathbf{1}(\boldsymbol{a}-\boldsymbol{d})$ were synthesized using the principle of Bignelli condensation by one pot reaction of the appropriate araldehyde, ethyl acetoacetate and thiourea in acidic medium. Confirmation of the chemical structure of the synthesized compounds (2a-x) was substintiated by different spectral data IR, ${ }^{1} H$-NMR, MS in addition to their microanalyses. The newly synthesized compounds were evaluated for their antimicrobial activities. The antibacterial and antifungal testing identified compounds $2 b, 2 e, 2 k, 2 l, 2 m, 2 n, 2 o, 2 p, 2 q, 2 r$ and $2 \boldsymbol{x}$ as the most effective agents in comparison to Chloramphenicol and Clotrimazole as reference antibacterial and antifungal drugs respectively.

\section{INTRODUCTION}

Bacterial infections are increasingly complicated by the ability to develop resistance to antimicrobial agents. Bacteria may be intrinsically resistant to $\geq 1$ class of antimicrobial agents or may acquire resistance by de novo mutation or via the acquisition of resistant genes from other organisms. ${ }^{1}$ The antimicrobial resistance is a global problem, probably due to the indiscriminate and irrational use of antibiotics, prescriptions for incorrect medicines or incorrect determinations of dose, route and/or duration. Another consideration is the uncertainty of patients receiving antibiotics about whether the quality of a generic medicine is equal to, greater than or less than its equivalent brand-name drug. The antimicrobial agent must be evaluated in-vitro and in-vivo in order to confirm their suitability for therapeutic use. ${ }^{2}$

Recently much interest has been focused on the chemistry of 2-thioxotetrahydropyrimidine-5-carboxylate and their derivatives, 
known as Bigenelli compounds, owing to their diverse range of biological properties such as antimicrobial, ${ }^{3-6}$ antitumor, ${ }^{5-8}$ anti-inflammatory and/or analgesic, ${ }^{9 \& 10}$ antioxidant, ${ }^{11}$ calcium channel blocker ${ }^{12-15}$ activities.

Motivated by the above documents, we tried to prepare the new derivatives of ethyl 6methyl-4-(substituted)-phenyl-2-(substituted)phenacylthio-1,4-dihydropyrimidine-5carboxylate (2a-x), aiming at the development of new antimicrobial agents.<smiles>CCOC(=O)C1=C(C)NC(=S)NC1Br</smiles>

Fig. 1: compound I

\section{EXPERIMENTAL}

Melting points were determined on an electrothermal melting point apparatus (Stuart Scientific, Model SMP1, UK) and were uncorrected. TLC was carried out using silica gel $60 \quad \mathrm{~F}_{254}$ precoated sheets (E. Merk, Darmstadt, Germany) and was visualized by UV lamp (Spectroline Model CM 10, USA), and/or iodine stains.

IR spectra ( $\mathrm{KBr}$ discs) were recorded on a Shimadzu IR-470 spectrometer (Shimadzu, Japan). ${ }^{1} \mathrm{H}-\mathrm{NMR}$ spectra were scanned on a Varian EM-360 L NMR spectrometer (60 $\mathrm{MHz}$ ), (Varian, USA). Chemical shifts are expressed in $\delta$ values (ppm) relative to tetramethylsilane (TMS) as an internal standard, using DMSO- $\mathrm{d}_{6}$ as a solvent. Elemental analyses were performed at the Micro Analytical Center, Cairo University, Cairo, Egypt. Mass spectra were recorded on a JEOL JMS 600 mass spectrometer (JEOL, Japan) at the Micro Analytical Center, Faculty of Science, Cairo University, Cairo and Central Lab., Assiut University, Assiut, Egypt.

Most of chemicals used were of commercial grade: $p$-bromobenzaldehyde, $p$ chlorobenzaldehyde, $p$-methylbenzaldehyde, $p$ methylacetophenone (Riedel-de Haën, Germany), benzaldehyde, thiourea (El Nasr Pharm. Co. Egypt), ethyl acetoacetate, acetophenone, $p$-bromoacetophenone, $p$-chloroacetophenone, $p$-methoxyacetophenone, bromine (Aldrich, Germany) and p-nitroacetophenone (MERCK-Schuchardt, Germany).

The key intermediates 2-thioxodihydropyrimidines (1a-d) were prepared by one pot reaction of the appropriate aldehyde, ethyl acetoacetate and thiourea in acidic medium according to Bignelli reaction.

General method for preparation of ethyl 6methyl-4-(substituted)phenyl-2-(substituted) phenacylthio-1,4-dihydropyrimidine-5carboxylate hydrobromide (2a-x)

A mixture of ethyl 6-methyl-4-(substitutedphenyl)-2-thioxo-1,4dihydro-pyrimidine-5-

carboxylate (1a-d) $(1.0 \mathrm{mmol})$, appropriate phenacyl bromide $(1.1 \mathrm{mmol})$ in anhydrous acetone $(25 \mathrm{ml})$ was refluxed for $30 \mathrm{~min}$, the formed precipitate was filtered, dried and crystallized from ethanol (Scheme 1, Table I).

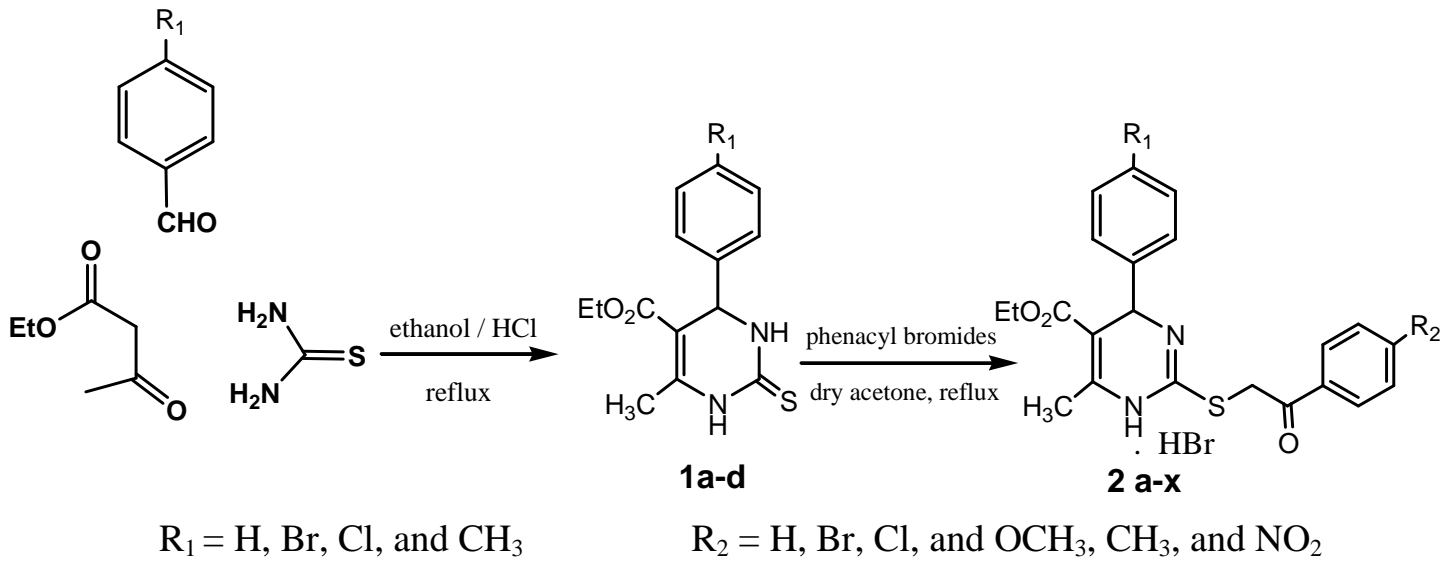

Scheme 1: Synthetic route for compounds (2a-x). 
Ethyl 6-methyl-4-phenyl-2-phenacylthio-1,4dihydropyrimidine-5-carboxylate hydro bromide (2a)

$\left.{ }^{1} \mathrm{H}-\mathrm{NMR} \quad\left(\mathrm{DMSO}_{\mathrm{d}}\right)_{6}\right) \delta: 1.15 \quad(3 \mathrm{H}, \mathrm{t}$, $\left.\mathrm{CH}_{2} \mathrm{CH}_{3}\right) ; 2.58\left(3 \mathrm{H}, \mathrm{s}, \mathrm{CH}_{3}\right) ; 3.80-4.30(4 \mathrm{H}, \mathrm{m}$, $\mathrm{SCH}_{2}, \mathrm{CH}_{2} \mathrm{CH}_{3}$ ); 5.55 (1H, s, pyr. C4); 7.66-8.0 $(10 \mathrm{H}, \mathrm{m}, \mathrm{Ar}-\mathrm{H}) ; 12.00(1 \mathrm{H}, \mathrm{b}$ s, exchangeable $\mathrm{NH})$. IR ( $\mathrm{KBr}) \mathrm{cm}^{-1}: 3475$ (NH stretching), 1700 (carbonyl group of the ester), 1649 (carbonyl group of phenacyl moiety) and 1514 $(\mathrm{C}=\mathrm{N}$ stretching vibration). MS (70 ev, EI): m/z (\%) (M. Wt 394.49): $\mathrm{M}^{+}$(394.74, 0.2\%) and $(198.71,100 \%)$.

Ethyl 6-methyl-4-phenyl-2-(4-bromophenacylthio)-1,4-dihydropyrimidine-5carboxyla-te hydrobromide (2b)

${ }^{1} \mathrm{H}-\mathrm{NMR} \quad\left(\mathrm{DMSO}-\mathrm{d}_{6}\right) \quad \delta: 1.10 \quad(3 \mathrm{H}, \mathrm{t}$, $\left.\mathrm{CH}_{2} \mathrm{CH}_{3}\right) ; 2.60\left(3 \mathrm{H}, \mathrm{s}, \mathrm{CH}_{3}\right) ; 3.80-4.40(4 \mathrm{H}, \mathrm{m}$, $\left.\mathrm{SCH}_{2}, \mathrm{CH}_{2} \mathrm{CH}_{3}\right) ; 5.60(1 \mathrm{H}$, s, pyr. $\mathrm{C} 4) ; 6.66-$ $7.50 \quad(9 \mathrm{H}, \quad \mathrm{m}, \quad \operatorname{Ar}-\mathrm{H}) ; 13.20(1 \mathrm{H}, \quad \mathrm{b}$ s, exchangeable $\mathrm{NH})$. IR $(\mathrm{KBr}) \mathrm{cm}^{-1}: 3480(\mathrm{NH}$ stretching), 1694 (carbonyl group of the ester), 1644 (carbonyl group of phenacyl moiety) and $1517(\mathrm{C}=\mathrm{N}$ stretching vibration). MS (70 ev, $\mathrm{EI}): \mathrm{m} / \mathrm{z}(\%)$ (M. Wt 473.38): $\mathrm{M}^{+}$(473.60, $8.9 \%), \mathrm{M}^{+}+2(475.50,6.9 \%)$ and $(139,00$, $100 \%)$

\section{Ethyl 6-methyl-4-phenyl-2-(4-chloro-} phenacylthio)-1,4-dihydropyrimidine-5carboxylate hydrobromide (2c)

${ }^{1} \mathrm{H}-\mathrm{NMR} \quad\left(\mathrm{DMSO}_{\mathrm{d}}\right) \quad \delta: 1.15 \quad(3 \mathrm{H}, \mathrm{t}$, $\left.\mathrm{CH}_{2} \mathrm{CH}_{3}\right) ; 2.60\left(3 \mathrm{H}, \mathrm{s}, \mathrm{CH}_{3}\right) ; 3.90-4.40(4 \mathrm{H}, \mathrm{m}$, $\left.\mathrm{SCH}_{2}, \mathrm{CH}_{2} \mathrm{CH}_{3}\right) ; 5.69(1 \mathrm{H}, \mathrm{s}$, pyr. C4); 6.70$7.70(9 \mathrm{H}, \quad \mathrm{m}, \quad \mathrm{Ar}-\mathrm{H}) ; 12.33(1 \mathrm{H}, \quad \mathrm{b}$ s, exchangeable $\mathrm{NH})$. IR $(\mathrm{KBr}) \mathrm{cm}^{-1}: 3425(\mathrm{NH}$ stretching), 1696 (carbonyl group of the ester), 1645 (carbonyl group of phenacyl moiety) and $1518(\mathrm{C}=\mathrm{N}$ stretching vibration). MS (70 ev, EI): $\mathrm{m} / \mathrm{z}(\%)$ (M. Wt 428.10): $\mathrm{M}^{+}$(427.84, $0.6 \%), \mathrm{M}^{+}+2$ (429.87, 0.1\%), $\mathrm{M}^{+}-18$ (409.90, $9.3 \%)$ and $(139.00,100 \%)$.

\section{Ethyl 6-methyl-4-phenyl-2-(4-methoxy- phenacylthio)-1,4-dihydropyrimidine-5- carboxyl-ate hydrobromide (2d)}

${ }^{1} \mathrm{H}-\mathrm{NMR} \quad\left(\mathrm{DMSO}-\mathrm{d}_{6}\right) \quad \delta: 1.10 \quad(3 \mathrm{H}, \mathrm{t}$, $\left.\mathrm{CH}_{2} \mathrm{CH}_{3}\right) ; 2.50\left(3 \mathrm{H}, \mathrm{s}, \mathrm{CH}_{3}\right) ; 3.97(3 \mathrm{H}, \mathrm{s}$, $\left.\mathrm{OCH}_{3}\right) ; 3.80-4.33\left(4 \mathrm{H}, \mathrm{m}, \mathrm{SCH}_{2}, \mathrm{CH}_{2} \mathrm{CH}_{3}\right)$; $5.83(1 \mathrm{H}, \mathrm{s}$, pyr. C4); 7.00-8.30 (9H, m, Ar-H); $11.97(1 \mathrm{H}, \mathrm{b}$ s, exchangeable $\mathrm{NH})$. IR $(\mathrm{KBr})$ $\mathrm{cm}^{-1}: 3460(\mathrm{NH}$ stretching), 1697 (carbonyl group of the ester), 1648 (carbonyl group of phenacyl moiety) and $1504(\mathrm{C}=\mathrm{N}$ stretching vibration).

Ethyl 6-methyl-4-phenyl-2-(4-methylphenacylthio)-1,4-dihydropyrimidine-5carboxylate hydrobromide (2e)

${ }^{1} \mathrm{H}-\mathrm{NMR} \quad\left(\mathrm{DMSO}-\mathrm{d}_{6}\right) \quad \delta: 1.10 \quad(3 \mathrm{H}, \quad \mathrm{t}$, $\left.\mathrm{CH}_{2} \mathrm{CH}_{3}\right) ; 2.30\left(3 \mathrm{H}, \mathrm{s}, \mathrm{CH}_{3}-\mathrm{C}_{6} \mathrm{H}_{4}\right) ; 2.50(3 \mathrm{H}, \mathrm{s}$, $\left.\mathrm{CH}_{3}\right) ; 3.80-4.33$ (4H, m, $\left.\mathrm{SCH}_{2}, \mathrm{CH}_{2} \mathrm{CH}_{3}\right) ; 5.50$ (1H, s, pyr. C4); $6.90-7.50$ (9H, m, Ar-H); 6.00 $(1 \mathrm{H}, \mathrm{b}$ s, exchangeable $\mathrm{NH})$. IR $(\mathrm{KBr}) \mathrm{cm}^{-1}$ : 3310 (NH stretching), 1691 (carbonyl group of the ester), 1666 (carbonyl group of phenacyl moiety) and 1512 (C=N stretching vibration).

Ethyl 6-methyl-4-phenyl-2-(4-nitrophenacylthio)-1,4-dihydropyrimidine-5-carboxylate hydrobromide (2f)

${ }^{1} \mathrm{H}-\mathrm{NMR} \quad\left(\right.$ DMSO- $\left._{6}\right) \quad \delta: 1.10 \quad(3 \mathrm{H}, \quad \mathrm{t}$, $\left.\mathrm{CH}_{2} \mathrm{CH}_{3}\right) ; 2.36\left(3 \mathrm{H}, \mathrm{s}, \mathrm{CH}_{3}\right) ; 3.60-4.15(4 \mathrm{H}, \mathrm{m}$, $\left.\mathrm{SCH}_{2}, \mathrm{CH}_{2} \mathrm{CH}_{3}\right) ; 5.30$ (1H, s, pyr. C4); 6.80$8.10(9 \mathrm{H}, \quad \mathrm{m}, \quad$ Ar- $\mathrm{H}) ; 11.00(1 \mathrm{H}, \quad \mathrm{b}$ s, exchangeable $\mathrm{NH})$. IR $(\mathrm{KBr}) \mathrm{cm}^{-1}: 3455(\mathrm{NH}$ stretching), 1696 (carbonyl group of the ester), 1647 (carbonyl group of phenacyl moiety) and 1514 ( $\mathrm{C}=\mathrm{N}$ stretching vibration).

\section{Ethyl 6-methyl-4-(4-bromophenyl)-2-} phenacylthio-1,4-dihydropyrimidine-5carboxylate hydrobromide (2g)

${ }^{1} \mathrm{H}-\mathrm{NMR} \quad\left(\mathrm{DMSO}_{6} \mathrm{~d}_{6}\right) \quad \delta: 1.10 \quad(3 \mathrm{H}, \quad \mathrm{t}$, $\left.\mathrm{CH}_{2} \mathrm{CH}_{3}\right) ; 2.43\left(3 \mathrm{H}, \mathrm{s}, \mathrm{CH}_{3}\right) ; 3.66-4.20(4 \mathrm{H}, \mathrm{m}$, $\left.\mathrm{SCH}_{2}, \mathrm{CH}_{2} \mathrm{CH}_{3}\right) ; 5.50(1 \mathrm{H}$, s, pyr. C4); 6.66$8.00(9 \mathrm{H}, \quad \mathrm{m}, \quad \mathrm{Ar}-\mathrm{H}) ; 12.00(1 \mathrm{H}, \quad \mathrm{b}$ s, exchangeable NH). IR (KBr) cm $\mathrm{cm}^{-1}: 3460(\mathrm{NH}$ stretching), 1701 (carbonyl group of the ester), 1644 (carbonyl group of phenacyl moiety) and 1513 ( $\mathrm{C}=\mathrm{N}$ stretching vibration).

Ethyl 6-methyl-4-(p-bromophenyl)-2-(4bromophenacylthio)-1,4-dihydropyrimidine5-carboxylate hydrobromide (2h)

${ }^{1} \mathrm{H}-\mathrm{NMR} \quad\left(\mathrm{DMSO}_{6}\right) \quad \delta: 1.10 \quad(3 \mathrm{H}, \mathrm{t}$, $\left.\mathrm{CH}_{2} \mathrm{CH}_{3}\right) ; 2.43\left(3 \mathrm{H}, \mathrm{s}, \mathrm{CH}_{3}\right) ; 3.80-4.30(4 \mathrm{H}, \mathrm{m}$, $\left.\mathrm{SCH}_{2}, \mathrm{CH}_{2} \mathrm{CH}_{3}\right) ; 5.50(1 \mathrm{H}$, s, pyr. C4); 7.00$8.00(8 \mathrm{H}, \quad \mathrm{m}, \quad \mathrm{Ar}-\mathrm{H}) ; 11.00(1 \mathrm{H}, \quad \mathrm{b} \quad \mathrm{s}$, exchangeable $\mathrm{NH})$. IR $(\mathrm{KBr}) \mathrm{cm}^{-1}: 3435(\mathrm{NH}$ stretching), 1707 (carbonyl group of the ester), 1648 (carbonyl group of phenacyl moiety) and 1514 ( $\mathrm{C}=\mathrm{N}$ stretching vibration). 
Ethyl 6-methyl-4-(4-bromophenyl)-2-(4chlorophenacylthio)-1,4-dihydropyrimidine5-carboxylate hydrobromide (2i)

${ }^{1} \mathrm{H}-\mathrm{NMR} \quad\left(\mathrm{DMSO}_{\mathrm{d}}\right) \quad \delta: 1.10 \quad(3 \mathrm{H}, \quad \mathrm{t}$, $\left.\mathrm{CH}_{2} \mathrm{CH}_{3}\right) ; 2.40\left(3 \mathrm{H}, \mathrm{s}, \mathrm{CH}_{3}\right) ; 3.80-4.30(4 \mathrm{H}, \mathrm{m}$, $\left.\mathrm{SCH}_{2}, \mathrm{CH}_{2} \mathrm{CH}_{3}\right) ; 5.66(1 \mathrm{H}, \mathrm{s}$, pyr. C4); 6.50$8.20(8 \mathrm{H}, \quad \mathrm{m}, \quad \operatorname{Ar}-\mathrm{H}) ; 12.30(1 \mathrm{H}, \quad$ b s, exchangeable NH). IR (KBr) $\mathrm{cm}^{-1}: 3440(\mathrm{NH}$ stretching), 1707 (carbonyl group of the ester), 1649 (carbonyl group of phenacyl moiety) and $1515(\mathrm{C}=\mathrm{N}$ stretching vibration). MS (70 ev, $\mathrm{EI}): \mathrm{m} / \mathrm{z}(\%)$ (M. Wt 507.83): $\mathrm{M}^{+}$(508.20, $2.5 \%)$, and $(138.80,100 \%)$.

Ethyl 6-methyl-4-(4-bromophenyl)-2-(4methoxyphenacylthio)-1,4-dihydropyrimidine-5-carboxylate hydrobromide ( $2 \mathbf{j}$ ) ${ }^{1} \mathrm{H}-\mathrm{NMR} \quad\left(\right.$ DMSO- $\left._{6}\right) \quad \delta: 1.10 \quad(3 \mathrm{H}, \quad \mathrm{t}$, $\left.\mathrm{CH}_{2} \mathrm{CH}_{3}\right) ; 2.40\left(3 \mathrm{H}, \mathrm{s}, \mathrm{CH}_{3}\right) ; 3.73(3 \mathrm{H}, \mathrm{s}$, $\left.\mathrm{OCH}_{3}\right)$; 3.66-4.30 (4H, m, $\mathrm{SCH}_{2}, \mathrm{CH}_{2} \mathrm{CH}_{3}$ ); 5.60 (1H, s, pyr. C4); 6.33-8.20 (8H, m, Ar-H); $11.90(1 \mathrm{H}, \mathrm{b} \mathrm{s}$, exchangeable $\mathrm{NH})$. IR $(\mathrm{KBr})$ $\mathrm{cm}^{-1}: 3395$ (NH stretching), 1693 (carbonyl group of the ester), 1643 (carbonyl group of phenacyl moiety) and 1498 ( $\mathrm{C}=\mathrm{N}$ stretching vibration).

Ethyl 6-methyl-4-(4-bromophenyl)-2-(4methylphenacylthio)-1,4-dihydropyrimidine-5-carboxylate hydrobromide (2k)

$\left.{ }^{1} \mathrm{H}-\mathrm{NMR} \quad\left(\mathrm{DMSO}_{\mathrm{d}}\right)_{6}\right) \quad \delta: 1.30 \quad(3 \mathrm{H}, \mathrm{t}$, $\left.\mathrm{CH}_{2} \mathrm{CH}_{3}\right) ; 2.40\left(6 \mathrm{H}, \mathrm{s}, 2 \mathrm{CH}_{3}\right) ; 3.80-4.30(4 \mathrm{H}$, $\left.\mathrm{m}, \mathrm{SCH}_{2}, \mathrm{CH}_{2} \mathrm{CH}_{3}\right) ; 5.66(1 \mathrm{H}$, s, pyr. C4); 6.80$8.10(8 \mathrm{H}, \quad \mathrm{m}, \quad \mathrm{Ar}-\mathrm{H}) ; 12.50(1 \mathrm{H}, \quad \mathrm{b} \quad \mathrm{s}$, exchangeable $\mathrm{NH})$. IR (KBr) $\mathrm{cm}^{-1}: 3420(\mathrm{NH}$ stretching), 1707 (carbonyl group of the ester), 1648 (carbonyl group of phenacyl moiety) and 1512 ( $\mathrm{C}=\mathrm{N}$ stretching vibration).

Ethyl 6-methyl-4-(4-bromophenyl)-2-(4nitrophenacylthio)-1,4-dihydropyrimidine5-carboxylate hydrobromide (2I)

${ }^{1} \mathrm{H}-\mathrm{NMR} \quad\left(\mathrm{DMSO}_{-} \mathrm{d}_{6}\right) \quad \delta: 1.50 \quad(3 \mathrm{H}, \mathrm{t}$, $\left.\mathrm{CH}_{2} \mathrm{CH}_{3}\right) ; 2.86\left(3 \mathrm{H}, \mathrm{s}, \mathrm{CH}_{3}\right) ; 4.00-5.00(4 \mathrm{H}, \mathrm{m}$, $\left.\mathrm{SCH}_{2}, \mathrm{CH}_{2} \mathrm{CH}_{3}\right) ; 5.96(1 \mathrm{H}, \mathrm{s}$, pyr. C4); 6.80$9.00 \quad(8 \mathrm{H}, \quad \mathrm{m}, \quad \operatorname{Ar}-\mathrm{H}) ; \quad 11.50 \quad(1 \mathrm{H}, \quad \mathrm{b} \quad \mathrm{s}$ exchangeable $\mathrm{NH})$. IR (KBr) $\mathrm{cm}^{-1}: 3450(\mathrm{NH}$ stretching), 1707 (carbonyl group of the ester), 1654 (carbonyl group of phenacyl moiety) and 1515 ( $\mathrm{C}=\mathrm{N}$ stretching vibration).
Ethyl 6-methyl-4-(4-chlorophenyl)-2phenacylthio-1,4-dihydropyrimidine-5carboxylate hydrobromide ( $2 \mathrm{~m})$

${ }^{1} \mathrm{H}-\mathrm{NMR} \quad\left(\mathrm{DMSO}_{6}\right) \quad \delta: 1.18 \quad(3 \mathrm{H}, \mathrm{t}$, $\left.\mathrm{CH}_{2} \mathrm{CH}_{3}\right) ; 2.51\left(3 \mathrm{H}, \mathrm{s}, \mathrm{CH}_{3}\right) ; 3.80-4.36(4 \mathrm{H}, \mathrm{m}$, $\left.\mathrm{SCH}_{2}, \mathrm{CH}_{2} \mathrm{CH}_{3}\right) ; 5.66(1 \mathrm{H}, \mathrm{s}$, pyr. C4); 6.66$7.66(9 \mathrm{H}, \quad \mathrm{m}, \quad \mathrm{Ar}-\mathrm{H}) ; 12.39(1 \mathrm{H}, \quad \mathrm{b} \quad \mathrm{s}$, exchangeable $\mathrm{NH})$. IR $(\mathrm{KBr}) \mathrm{cm}^{-1}: 3450(\mathrm{NH}$ stretching), 1705 (carbonyl group of the ester), 1650 (carbonyl group of phenacyl moiety) and 1513 ( $\mathrm{C}=\mathrm{N}$ stretching vibration).

Ethyl 6-methyl-4-(4-chlorophenyl)-2-(4bromophenacylthio)-1,4-dihydropyrimidine5-carboxylate hydrobromide (2n)

${ }^{1} \mathrm{H}-\mathrm{NMR} \quad\left(\mathrm{DMSO}_{6}\right) \quad \delta: 1.10 \quad(3 \mathrm{H}, \mathrm{t}$, $\left.\mathrm{CH}_{2} \mathrm{CH}_{3}\right) ; 2.50\left(3 \mathrm{H}, \mathrm{s}, \mathrm{CH}_{3}\right) ; 3.80-4.33(4 \mathrm{H}, \mathrm{m}$, $\left.\mathrm{SCH}_{2}, \mathrm{CH}_{2} \mathrm{CH}_{3}\right) ; 5.60(1 \mathrm{H}$, s, pyr. C4); 6.70$8.00(8 \mathrm{H}, \quad \mathrm{m}, \quad$ Ar-H $) ; 12.00 \quad(1 \mathrm{H}, \quad$ b s, exchangeable NH). IR (KBr) $\mathrm{cm}^{-1}: 3500(\mathrm{NH}$ stretching), 1706 (carbonyl group of the ester), 1649 (carbonyl group of phenacyl moiety) and $1513(\mathrm{C}=\mathrm{N}$ stretching vibration). MS (FAB): $\mathrm{m} / \mathrm{z}(\%)\left(\mathrm{M}\right.$. Wt 507.83): $(\mathrm{M}+\mathrm{H})^{+}(508.20$, $0.3 \%),(\mathrm{M}+\mathrm{H})^{+}+2(510.02,0.5 \%)$ and $(475.30$, $100 \%)$.

Ethyl 6-methyl-4-(4-chlorophenyl)-2-(4chlorophenacylthio)-1,4-dihydropyrimidine5-carboxylate hydrobromide (2o)

${ }^{1} \mathrm{H}-\mathrm{NMR} \quad\left(\mathrm{DMSO}_{\mathrm{C}}\right) \quad \delta: 1.10 \quad(3 \mathrm{H}, \mathrm{t}$, $\left.\mathrm{CH}_{2} \mathrm{CH}_{3}\right) ; 2.50\left(3 \mathrm{H}, \mathrm{s}, \mathrm{CH}_{3}\right) ; 3.80-4.23(4 \mathrm{H}, \mathrm{m}$, $\left.\mathrm{SCH}_{2}, \mathrm{CH}_{2} \mathrm{CH}_{3}\right) ; 5.46(1 \mathrm{H}$, s, pyr. C4); 6.80$7.80(8 \mathrm{H}, \quad \mathrm{m}, \quad \operatorname{Ar}-\mathrm{H}) ; 11.59(1 \mathrm{H}, \quad \mathrm{b} \quad \mathrm{s}$, exchangeable NH). IR (KBr) $\mathrm{cm}^{-1}: 3395(\mathrm{NH}$ stretching), 1707 (carbonyl group of the ester), 1649 (carbonyl group of phenacyl moiety) and 1514 ( $\mathrm{C}=\mathrm{N}$ stretching vibration). MS (70 ev, $\mathrm{EI}): \mathrm{m} / \mathrm{z}(\%)\left(\mathrm{M}\right.$. Wt 462.06): $\mathrm{M}^{+}$(462.00, $5.0 \%)$ and $(139.00,100 \%)$.

Ethyl 6-methyl-4-(4-chlorophenyl)-2-(4methoxyphenacylthio)-1,4-dihydropyrimidine-5-carboxylate hydrobromide (2p)

${ }^{1} \mathrm{H}-\mathrm{NMR} \quad\left(\mathrm{DMSO}_{6}\right) \quad \delta: 1.10 \quad(3 \mathrm{H}, \mathrm{t}$, $\left.\mathrm{CH}_{2} \mathrm{CH}_{3}\right) ; 2.43\left(3 \mathrm{H}, \mathrm{s}, \mathrm{CH}_{3}\right) ; 3.80(3 \mathrm{H}, \mathrm{s}$, $\left.\mathrm{OCH}_{3}\right)$; 3.66-4.23 (4H, m, $\mathrm{SCH}_{2}, \mathrm{CH}_{2} \mathrm{CH}_{3}$ ); $5.46(1 \mathrm{H}, \mathrm{s}$, pyr. C4); 6.80-7.90 (8H, m, Ar-H); $12.59(1 \mathrm{H}, \mathrm{b}$ s, exchangeable $\mathrm{NH})$. IR $(\mathrm{KBr})$ $\mathrm{cm}^{-1}$ : 3450 (NH stretching), 1695 (carbonyl group of the ester), 1643 (carbonyl group of phenacyl moiety) and 1499 ( $\mathrm{C}=\mathrm{N}$ stretching vibration). 
Ethyl 6-methyl-4-(4-chlorophenyl)-2-(4methylphenacylthio)-1,4-dihydropyrimidine-5-carboxylate hydrobromide (2q)

${ }^{1} \mathrm{H}-\mathrm{NMR} \quad\left(\mathrm{DMSO}_{6} \mathrm{~d}_{6}\right) \quad \delta: 1.10 \quad(3 \mathrm{H}, \mathrm{t}$, $\left.\mathrm{CH}_{2} \mathrm{CH}_{3}\right) ; 2.33\left(3 \mathrm{H}, \mathrm{s}, \mathrm{CH}_{3}-\mathrm{C}_{6} \mathrm{H}_{4^{-}}\right) ; 2.45(3 \mathrm{H}, \mathrm{s}$, $\left.\mathrm{CH}_{3}\right) ; 3.66-4.40\left(4 \mathrm{H}, \mathrm{m}, \mathrm{SCH}_{2}, \mathrm{CH}_{2} \mathrm{CH}_{3}\right) ; 5.43$ $(1 \mathrm{H}, \mathrm{s}$, pyr. C4); 6.80-7.50 (8H, m, Ar-H); $11.00(1 \mathrm{H}, \mathrm{b}$ s, exchangeable $\mathrm{NH})$. IR $(\mathrm{KBr})$ $\mathrm{cm}^{-1}$ : 3440 (NH stretching), 1706 (carbonyl group of the ester), 1648 (carbonyl group of phenacyl moiety) and $1512(\mathrm{C}=\mathrm{N}$ stretching vibration).

Ethyl 6-methyl-4-(4-chlorophenyl)-2-(4nitrophenacylthio)-1,4-dihydropyrimidine5-carboxylate hydrobromide (2r)

${ }^{1} \mathrm{H}-\mathrm{NMR} \quad\left(\mathrm{DMSO}^{\left.-\mathrm{d}_{6}\right)} \quad \delta: 1.00 \quad(3 \mathrm{H}, \mathrm{t}\right.$, $\left.\mathrm{CH}_{2} \mathrm{CH}_{3}\right) ; 2.33\left(3 \mathrm{H}, \mathrm{s}, \mathrm{CH}_{3}\right) ; 3.66-4.66(4 \mathrm{H}, \mathrm{m}$, $\left.\mathrm{SCH}_{2}, \underline{\mathrm{CH}}_{2} \mathrm{CH}_{3}\right) ; 5.40(1 \mathrm{H}$, s, pyr. C4); 6.66$8.33(8 \mathrm{H}, \quad \mathrm{m}, \quad \operatorname{Ar}-\mathrm{H}) ; 11.30(1 \mathrm{H}, \quad \mathrm{b}$ s, exchangeable $\mathrm{NH})$. IR $(\mathrm{KBr}) \mathrm{cm}^{-1}: 3440(\mathrm{NH}$ stretching), 1707 (carbonyl group of the ester), 1652 (carbonyl group of phenacyl moiety) and 1515 ( $\mathrm{C}=\mathrm{N}$ stretching vibration).

Ethy 6-methyl-4-(4-methylphenyl)-2phenacylthio-1,4-dihydropyrimidine-5carboxylate hydrobromide (2s)

${ }^{1} \mathrm{H}-\mathrm{NMR} \quad\left(\mathrm{DMSO}-\mathrm{d}_{6}\right) \quad \delta: 1.16 \quad(3 \mathrm{H}, \mathrm{t}$, $\left.\mathrm{CH}_{2} \mathrm{CH}_{3}\right) ; 2.30\left(3 \mathrm{H}, \mathrm{s}, \mathrm{CH}_{3}-\mathrm{C}_{6} \mathrm{H}_{4}\right) ; 2.50(3 \mathrm{H}, \mathrm{s}$, $\left.\mathrm{CH}_{3}\right) ; 3.80-4.40\left(4 \mathrm{H}, \mathrm{m}, \mathrm{SCH}_{2}, \mathrm{CH}_{2} \mathrm{CH}_{3}\right) ; 5.50$ $(1 \mathrm{H}$, s, pyr. C4); 6.60-8.00 (9H, m, Ar-H); $12.39(1 \mathrm{H}, \mathrm{b} \mathrm{s}$, exchangeable $\mathrm{NH})$. IR $(\mathrm{KBr})$ $\mathrm{cm}^{-1}$ : 3405 (NH stretching), 1702 (carbonyl group of the ester), 1657 (carbonyl group of phenacyl moiety) and $1519(\mathrm{C}=\mathrm{N}$ stretching vibration).

Ethyl 6-methyl-4-(4-methylphenyl)-2-(4bromophenacylthio)-1,4-dihydropyrimidine5-carboxylate hydrobromide (2t)

${ }^{1} \mathrm{H}-\mathrm{NMR} \quad\left(\mathrm{DMSO}^{\left.-\mathrm{d}_{6}\right)} \quad \delta: 1.16 \quad(3 \mathrm{H}, \quad \mathrm{t}\right.$, $\left.\mathrm{CH}_{2} \mathrm{CH}_{3}\right) ; 2.30\left(3 \mathrm{H}, \mathrm{s}, \mathrm{CH}_{3}-\mathrm{C}_{6} \mathrm{H}_{4}-\right) ; 2.50(3 \mathrm{H}, \mathrm{s}$, $\left.\mathrm{CH}_{3}\right) ; 3.86-4.33$ (4H, m, $\left.\mathrm{SCH}_{2}, \mathrm{CH}_{2} \mathrm{CH}_{3}\right) ; 5.50$ $(1 \mathrm{H}, \mathrm{s}$, pyr. C4); $6.60-8.00(8 \mathrm{H}, \mathrm{m}, \mathrm{Ar}-\mathrm{H})$; $12.00(1 \mathrm{H}, \mathrm{b}$ s exchangeable $\mathrm{NH})$. IR $(\mathrm{KBr})$ $\mathrm{cm}^{-1}: 3430$ (NH stretching), 1707 (carbonyl group of the ester), 1647 (carbonyl group of phenacyl moiety) and $1515(\mathrm{C}=\mathrm{N}$ stretching vibration).
Ethyl 6-methyl-4-(4-methylphenyl)-2-(4chlorophenacylthio)-1,4-dihydropyrimidine5-carboxylate hydrobromide (2u)

${ }^{1} \mathrm{H}-\mathrm{NMR} \quad\left(\mathrm{DMSO}-\mathrm{d}_{6}\right) \quad \delta: 1.10 \quad(3 \mathrm{H}, \quad \mathrm{t}$, $\left.\mathrm{CH}_{2} \mathrm{CH}_{3}\right) ; 2.26\left(3 \mathrm{H}, \mathrm{s}, \mathrm{CH}_{3}-\mathrm{C}_{6} \mathrm{H}_{4}-\right) ; 2.46(3 \mathrm{H}, \mathrm{s}$, $\left.\mathrm{CH}_{3}\right) ; 3.60-4.33\left(4 \mathrm{H}, \mathrm{m}, \mathrm{SCH}_{2}, \mathrm{CH}_{2} \mathrm{CH}_{3}\right) ; 5.43$ $(1 \mathrm{H}, \mathrm{s}$, pyr. C4); 6.50-8.33 (8H, m, Ar-H); $12.45\left(1 \mathrm{H}, \mathrm{b}\right.$ s, $\mathrm{N}_{1} \mathrm{H}$ exchangeable $\left.\mathrm{NH}\right)$. IR $(\mathrm{KBr}) \mathrm{cm}^{-1}: 3390 \quad(\mathrm{NH}$ stretching), 1707 (carbonyl group of the ester), 1648 (carbonyl group of phenacyl moiety) and $1514(\mathrm{C}=\mathrm{N}$ stretching vibration).

Ethyl 6-methyl-4-(4-methylphenyl)-2-(4methoxyphenacylthio)-1,4-dihydropyrimidine-5-carboxylate hydrobromide (2v)

${ }^{1} \mathrm{H}-\mathrm{NMR} \quad\left(\mathrm{DMSO}_{6}\right) \quad \delta: 1.16 \quad(3 \mathrm{H}, \mathrm{t}$, $\left.\mathrm{CH}_{2} \mathrm{CH}_{3}\right) ; 2.30\left(3 \mathrm{H}, \mathrm{s}, \mathrm{CH}_{3}-\mathrm{C}_{6} \mathrm{H}_{4}-\right) ; 2.50(3 \mathrm{H}, \mathrm{s}$, $\left.\mathrm{CH}_{3}\right) ; 3.83\left(3 \mathrm{H}, \mathrm{s}, \mathrm{OCH}_{3}\right) ; 3.60-4.33(4 \mathrm{H}, \mathrm{m}$, $\left.\mathrm{SCH}_{2}, \mathrm{CH}_{2} \mathrm{CH}_{3}\right) ; 5.50$ (1H, s, pyr. C4); 6.60$8.20(8 \mathrm{H}, \quad \mathrm{m}, \quad \mathrm{Ar}-\mathrm{H}) ; 11.55(1 \mathrm{H}, \quad \mathrm{b} \quad \mathrm{s}$, exchangeable $\mathrm{NH})$. IR $(\mathrm{KBr}) \mathrm{cm}^{-1}: 3410(\mathrm{NH}$ stretching), 1695 (carbonyl group of the ester), 1643 (carbonyl group of phenacyl moiety) and 1499 ( $\mathrm{C}=\mathrm{N}$ stretching vibration).

Ethyl 6-methyl-4-(4-methylphenyl)-2-(4methylphenacylthio)-1,4-dihydropyrimidine-5-carboxylate hydrobromide $(2 \mathrm{w})$

${ }^{1} \mathrm{H}-\mathrm{NMR} \quad\left(\right.$ DMSO- $\left._{6}\right) \quad \delta: 1.20 \quad(3 \mathrm{H}, \mathrm{t}$, $\left.\mathrm{CH}_{2} \mathrm{CH}_{3}\right) ; 2.30\left(6 \mathrm{H}, \mathrm{s}, 2 \mathrm{CH}_{3}-\mathrm{C}_{6} \mathrm{H}_{4}-\right) ; 2.50(3 \mathrm{H}$, s, $\left.\mathrm{CH}_{3}\right) ; 3.90-4.40\left(4 \mathrm{H}, \mathrm{m}, \mathrm{SCH}_{2}, \mathrm{CH}_{2} \mathrm{CH}_{3}\right)$; $5.80(1 \mathrm{H}, \mathrm{s}$, pyr. C4); 7.00-8.20 (8H, m, Ar-H); $11.20(1 \mathrm{H}, \mathrm{b}$ s, exchangeable $\mathrm{NH})$. IR $(\mathrm{KBr})$ $\mathrm{cm}^{-1}: 3390(\mathrm{NH}$ stretching), 1698 (carbonyl group of the ester), 1662 (carbonyl group of phenacyl moiety) and $1500(\mathrm{C}=\mathrm{N}$ stretching vibration).

Ethyl 6-methyl-4-(4-methylphenyl)-2-(4nitrophenacylthio)-1,4-dihydropyrimidine5-carboxylate hydrobromide (2x)

${ }^{1} \mathrm{H}-\mathrm{NMR} \quad\left(\mathrm{DMSO}-\mathrm{d}_{6}\right) \quad \delta: 1.10 \quad(3 \mathrm{H}, \mathrm{t}$, $\left.\mathrm{CH}_{2} \mathrm{CH}_{3}\right) ; 2.20\left(3 \mathrm{H}, \mathrm{s}, \mathrm{CH}_{3}-\mathrm{C}_{6} \mathrm{H}_{4}-\right) ; 2.43(3 \mathrm{H}, \mathrm{s}$, $\left.\mathrm{CH}_{3}\right) ; 3.80-4.30\left(4 \mathrm{H}, \mathrm{m}, \mathrm{SCH}_{2}, \mathrm{CH}_{2} \mathrm{CH}_{3}\right) ; 5.43$ $(1 \mathrm{H}, \mathrm{s}$, pyr. $\mathrm{C} 4) ; 6.50-8.00(8 \mathrm{H}, \mathrm{m}, \mathrm{Ar}-\mathrm{H})$; $12.69(1 \mathrm{H}, \mathrm{b} \mathrm{s}$, exchangeable $\mathrm{NH})$. IR $(\mathrm{KBr})$ $\mathrm{cm}^{-1}$ : 3425 (NH stretching), 1707 (carbonyl group of the ester), 1651 (carbonyl group of phenacyl moiety) and $1514(\mathrm{C}=\mathrm{N}$ stretching vibration). 


\section{Antimicrobial screening}

\section{Antibacterial activity \\ Organisms}

Five bacterial species representing both Gram-positive and Gram-negative strains were used to test the antibacterial activities of the new compounds: Staphylococcus aureus (AUMC No. B-54) and Bacillus cereus (AUMC NoB-5) as representatives of Grampositive strains, and Escherichia coli (AUMC No.B-53), Pseudomonas aeruginosa (AUMC No. B-73), as well as Serratia marcescens (AUMC No. B-55) as representatives of Gramnegative strains.

\section{Materials and methods ${ }^{2 \& 16}$}

To prepare inocula for bioassay, bacterial strains were individually cultured for $24 \mathrm{hrs}$ in $100 \mathrm{ml}$ conical flasks containing $30 \mathrm{ml}$ nutrient broth medium. Bioassay was done in $10 \mathrm{~cm}$ sterile plastic Petri plates in which bacterial suspension $(1 \mathrm{~m} /$ plate $)$ and $15 \mathrm{ml}$ Nutrient agar medium (15 ml/plate) were poured. After solidification of the media, $5 \mathrm{~mm}$ diameter cavities were cut in the solidified agar (4 cavities/plate) using sterile cork borer. Tested compounds dissolved in dimethyl sulfoxide (DMSO) at $100 \mu \mathrm{mol} / \mathrm{ml}$ were pipetted in the cavities $(20 \mu \mathrm{l} /$ cavity $)$. Cultures were then incubated at $28^{\circ} \mathrm{C}$ for $48 \mathrm{hrs}$. Results were read as the diameter (in $\mathrm{mm}$ ) of inhibition zone around cavities.

\section{Antifungal activity Organisms}

Six pathogenic, phytogenic, or foodpoisning fungal species were used in the present study: Candida albicans (AUMC No. 418), Geotrichum candidum (AUMC No. 226), Aspergillus flavus (AUMC No. 1276), Trichophyton rubrum (AUMC No. 1804), Scopulariopsis brevicaulis (AUMC No. 729), Fusarium oxysporum (AUMC No. 5119).

\section{Materials and method ${ }^{2 \& 16}$}

To prepare inocula for bioassay, Fungi were grown for 7 days in $100 \mathrm{ml}$ conical flasks containing $30 \mathrm{ml}$ sabouraud's dextrose broth. Bioassay was done in $10 \mathrm{~cm}$ sterile plastic Petri plates in which fungal suspension $(1 \mathrm{~m} /$ plate) and $15 \mathrm{ml}$ sabouraud 's dextrose agar medium $(15 \mathrm{ml} /$ plate $)$ were poured. After solidification of the media, $5 \mathrm{~mm}$ diameter cavities were cut in the solidified agar (4 cavities/plate) using sterile cork borer. Tested compounds dissolved in dimethyl sulfoxide (DMSO) at $100 \mu \mathrm{mol} / \mathrm{ml}$ were pipetted in the cavities $(20 \mu \mathrm{l} /$ cavity). Cultures were then incubated at $28^{\circ} \mathrm{C}$ up to 7 days. Results were read as the diameter (in $\mathrm{mm}$ ) of inhibition zone around cavities.

For determination of the minimum inhibitory concentrations (MICs), tested compounds giving positive results were diluted with DMSO to prepare a series of descending concentrations down to $0.39 \mu \mathrm{mol} / \mathrm{ml}$. diluted compounds were similarly assayed as mentioned before and the least concentration (below which no activity) was recorded as the MIC.

\section{RESULTS AND DISCUSSION}

\section{Chemistry}

Ethyl 6-methyl-4-(substituted)phenyl-2thioxo-1,2,3,4-tetrahydropyrimidine-5-carboxylates (1a-d) were synthesized according to a reported procedure through reaction of the appropriate aldehyde with thiourea and ethylacetoacetate ${ }^{17-19}$. S-alkylation of compounds (1a-d) with phenacyl bromides in dry acetone afforded compounds (2a-x) as their hydrobromide salts in an excellent yields (8593\%). It was reported that, S-alkylation supercsedes the N-alkylation due to the difference in nucleophilicity between sulfur and nitrogen atoms ${ }^{7 \& 8}$. Structures of compounds (1a-d) were confirmed by comparison with the reported data ${ }^{17-19}$. Structures of the synthesized compounds (2a-x) were verified by IR, ${ }^{1} \mathrm{H}-\mathrm{NMR}$, mass spectra in addition to elemental microanalyses. IR spectra of compounds (2a-x) revealed absorption bands at $3505-3310 \mathrm{~cm}^{-1}$ indicating $\mathrm{NH}$ stretching, $1707-1691 \mathrm{~cm}^{-1}$ and $1666-1643 \mathrm{~cm}^{-1}$ for the carbonyl groups of the ester and phenacyl moieties, respectively. In addition to a strong absorption band at $1519-1498 \mathrm{~cm}^{-1}$ indicating $\mathrm{C}=\mathrm{N}$ stretching vibration. ${ }^{1} \mathrm{H}-\mathrm{NMR}$ revealed a triplet signal of $\mathrm{CH}_{3}$ of the ethyl group at 1.00 $1.50 \mathrm{ppm}$, quartet signal of $\mathrm{CH}_{2}$ of the ethyl group at 3.60-4.00 ppm, singlet signal of $\mathrm{SCH}_{2}$ of the phenacyl moiety at $3.80-4.15 \mathrm{ppm}$, multiplet at $6.30-8.30 \mathrm{ppm}$ indicating aromatic protons and broad singlet signal at 11.97-13.20 ppm attributed to $\mathrm{NH}$ group. Moreover, mass spectra (EI) of compounds $\mathbf{2 a}, \mathbf{2 b}, \mathbf{2 c}, \mathbf{2 i}$ and $\mathbf{2 o}$ 
revealed a molecular ion peaks $\left(\mathrm{M}^{+}\right)$at 394.74 , $473.60,427.84, \quad 508.20$ and $462.00 \mathrm{~m} / \mathrm{z}$ corresponding to their molecular weights, respectively. Compounds $\mathbf{2 b}$ and $\mathbf{2 c}$ showed $\mathrm{M}^{+}+2$ at 475.50 and $429.87 \mathrm{~m} / \mathrm{z}$, respectively. Compound 2a showed a base peak at 198.71 $\mathrm{m} / \mathrm{z}$ while compounds $\mathbf{2 b}, \mathbf{2 c}, \mathbf{2 i}$ and $\mathbf{2 o}$ showed a base peak at $139.00 \mathrm{~m} / \mathrm{z}$. On the other hand, mass spectra $(\mathrm{FAB})$ of compound $2 \mathbf{n}$ showed $(\mathrm{M}+\mathrm{H})^{+}$at 508.20, $(\mathrm{M}+\mathrm{H})^{+}+2$ at 510.02 and base peak at $475.30 \mathrm{~m} / \mathrm{z}$. physicochemical data of compounds (2a-x) are shown in table I and spectral data in the experimental section.

\section{Antimicrobial activities Antibacterial activity}

The newly synthesized compounds (2a-x) were tested for their in-vitro antibacterial activity against Staphylococcus aureus (AUMC No. B-54) and Bacillus cereus (AUMC No. B5) as representatives of Gram-positive strains and Escherichia coli (AUMC No. B-53), Pseudomonas aeruginosa (AUMC No. B-73) and Serratia marcescens (AUMC No. B-55) as representatives of Gram-negative ones.

The test compounds (2a-x) were assayed using the standard agar cup diffusion method ${ }^{16}$ at a concentration of $100 \mu \mathrm{mol} / \mathrm{mL}$ and those giving positive results were diluted with DMSO to prepare a series of descending concentrations down to $0.39 \mu \mathrm{mol} / \mathrm{mL}$ and were similarly assayed and the test concentration (below which no activity) was recorded as the MIC.

Results of the antibacterial activity, table II, indicated that at a concentration of 100 $\mu \mathrm{mol} / \mathrm{mL}$ most of the test compounds were active against most of the used bacterial strains. Compounds 2a, 2s and $2 \mathbf{v}$ were completely inactive against all used organisms. Compounds $\mathbf{2 b}, \mathbf{2 m}$ and $\mathbf{2 w}$ were active only against Staphylococcus aureus and compounds 2c, $2 \mathbf{f}$ and $\mathbf{2 g}$ were active only against Bacillus cereus. In addition, the active compounds (2a$\mathbf{x})$ showed $51.9-85.2 \%$ antibacterial activity of that of choramphenicol against Staphylococcus aureus, 40.6-78.1\% against Bacillus cereus, 53.3-76.7\% against Escherichia coli, 66.7$83.3 \%$ against Pseudomonas aeruginosa and 31.7-48.8\% against Serratia marcescens. Moreover, the variation of the antibacterial activity with concentrations was indicated in table III. It was noted that, the most sensitive organisms to the test compounds were Staphylococcus aureus and Pseudomonas aeruginosa.
Again, from tables III and IV, compounds 2n, $2 \mathbf{o}$ and $2 \mathbf{r}$ have a wide spectrum of antibacterial activity being able to inhibit all test bacterial organisms with MICs ranging from 100 to $0.39 \mu \mathrm{mol} / \mathrm{mL}$. Compounds $\mathbf{2 i}, \mathbf{2 k}$ and $2 \mathbf{l}$ were effective against four out of five bacterial strains with MICs ranging from 100 up to $6.25 \mu \mathrm{mol} / \mathrm{mL}$. It is noteworthy to mention that, the most active compounds comprise in their structures an electron withdrawing group $\left(\mathrm{R}_{1}=\mathrm{Cl} ; \mathrm{R}_{2}=\mathrm{Br}, \mathrm{Cl}\right.$, or $\left.\mathrm{NO}_{2}\right)$ while the least active compounds comprise in their structures an electron donating group $\left(\mathrm{R}_{1}=\mathrm{H}, \mathrm{CH}_{3} ; \mathrm{R}_{2}=\mathrm{OCH}_{3}, \mathrm{CH}_{3}\right)$.

\section{Antifungal activity}

Compounds (2a-x) were tested for their in-vitro antifungal activity using the standard agar disc diffusion method against Candida albicans (AUMC No. 418), Geotrichum candidum (AUMC No. 226), Fusarium oxysporum (AUMC No. 5119), Aspergillus flavus (AUMC No. 1276), Trichophyton rubrum (AUMC No. 1804) and Scopulariopsis brevicaulis (AUMC No. 729). The results of the antifungal activity are given in table $\mathrm{V}$ and expressed as inhibition zones in $\mathrm{mm}$ using Clotrimazole as a reference drug.

Results of the antifungal activity, table $\mathrm{V}$, indicated that at a concentration of 100 $\mu \mathrm{mol} / \mathrm{mL}$ all compounds were completely inactive against Aspergillus flavus and Scopulariopsis brevicaulis except 2f. Compound $\mathbf{2 w}$ was active only against Trichophyton rubrum. Compounds 2a and 2c were possessed antifungal activity equal to that of the reference drug against Fusarium oxysporum and Geotrichum candidum, respectively. In addition, the active compounds (2a-x) showed $53.3-80.0 \%$ antifungal activity of that of Clotrimazole against Candida albicans with MICs ranged from 6.25-100 $\mu \mathrm{mol} / \mathrm{mL}, \quad 54.2-100 \%$ against Geotrichum candidum, $\quad 36.4-100 \%$ against Fusarium oxysporum and $34.3-97.1 \%$ against Trichophyton rubrum.

Also, the results indicated that compound $2 \mathbf{f}$ has a wide spectrum of antifungal activity being able to inhibit all test fungal organisms with MICs ranging from 50 to $12.5 \mu \mathrm{mol} / \mathrm{mL}$. Compounds $\mathbf{2 b}$ and $\mathbf{2 q}$ were effective against four out of six fungal strains with MICs ranging from 100 to $6.25 \mu \mathrm{mol} / \mathrm{mL}$. Again, it is noteworthy to mention that the most active 
compounds comprise in their structures an electron withdrawing group $\left(\mathrm{R}_{1}=\mathrm{H}, \mathrm{Cl} ; \mathrm{R}_{2}=\right.$ $\mathrm{Br}, \mathrm{NO}_{2}$ ) while the least active compounds comprise in their structures an electron donating group $\left(\mathrm{R}_{1}=\mathrm{CH}_{3} ; \mathrm{R}_{2}=\mathrm{CH}_{3}, \mathrm{OCH}_{3}\right)$.

Table I: The physicochemical data of compounds (2a-x).<smiles>[R2]OC(=O)C1=C(C)NC([Sn]CC(=O)c2ccc(Br)cc2)=NC1c1ccc(Br)cc1</smiles>

\begin{tabular}{|c|c|c|c|c|c|c|c|c|c|c|}
\hline \multirow[t]{2}{*}{ No. } & \multirow{2}{*}{$\mathrm{R}_{1}$} & \multirow{2}{*}{$\mathrm{R}_{2}$} & \multirow{2}{*}{$\begin{array}{l}\text { M.p. } \\
\left({ }^{\circ} \mathrm{C}\right)\end{array}$} & \multirow{2}{*}{$\begin{array}{l}\text { Yield } \\
(\%)\end{array}$} & \multirow{2}{*}{$\mathrm{R} f^{*}$} & \multirow{2}{*}{$\begin{array}{c}\mathrm{C} \log \\
\mathrm{p}^{* *}\end{array}$} & \multirow{2}{*}{$\begin{array}{l}\text { Mol. Formula } \\
\text { (Mol. Wt.) }\end{array}$} & \multicolumn{3}{|c|}{$\begin{array}{l}\text { Microanalyses } \\
\text { Calcd/ Found } \\
\end{array}$} \\
\hline & & & & & & & & $\mathrm{C} \%$ & $\mathrm{C} \%$ & $\mathrm{C} \%$ \\
\hline $2 a$ & $\mathrm{H}$ & $\mathrm{H}$ & $172-3$ & 93 & 0.38 & 6.13 & $\begin{array}{c}\mathrm{C}_{22} \mathrm{H}_{23} \mathrm{BrN}_{2} \mathrm{O}_{3} \mathrm{~S} \\
(475.4)\end{array}$ & $\begin{array}{l}55.58 \\
55.79\end{array}$ & $\begin{array}{l}4.88 \\
4.70\end{array}$ & $\begin{array}{l}5.89 \\
5.84\end{array}$ \\
\hline $\mathbf{2 b}$ & $\mathrm{H}$ & $\mathrm{Br}$ & 175 & 92 & 0.33 & 8.36 & $\begin{array}{c}\mathrm{C}_{22} \mathrm{H}_{22} \mathrm{Br}_{2} \mathrm{~N}_{2} \mathrm{O}_{3} \mathrm{~S} \\
(554.29)\end{array}$ & $\begin{array}{l}47.67 \\
47.41 \\
\end{array}$ & $\begin{array}{l}4.00 \\
3.94 \\
\end{array}$ & $\begin{array}{l}5.05 \\
4.70 \\
\end{array}$ \\
\hline $2 c$ & $\mathrm{H}$ & $\mathrm{Cl}$ & $174-6$ & 90 & 0.31 & 8.21 & $\begin{array}{c}\mathrm{C}_{22} \mathrm{H}_{22} \mathrm{BrClN}_{2} \mathrm{O}_{3} \mathrm{~S} \\
(509.84)\end{array}$ & $\begin{array}{l}51.83 \\
52.10\end{array}$ & $\begin{array}{l}4.35 \\
4.54\end{array}$ & $\begin{array}{l}5.49 \\
5.51\end{array}$ \\
\hline $2 d$ & $\mathrm{H}$ & $\mathrm{OCH}_{3}$ & 219 & 91 & 0.48 & 7.64 & $\begin{array}{c}\mathrm{C}_{23} \mathrm{H}_{25} \mathrm{BrN}_{2} \mathrm{O}_{4} \mathrm{~S} \\
(505.42)\end{array}$ & $\begin{array}{l}54.66 \\
55.00\end{array}$ & $\begin{array}{l}4.99 \\
5.18\end{array}$ & $\begin{array}{l}5.54 \\
5.50\end{array}$ \\
\hline $2 \mathrm{e}$ & $\mathrm{H}$ & $\mathrm{CH}_{3}$ & 156 & 92 & 0.42 & 7.92 & $\begin{array}{c}\mathrm{C}_{23} \mathrm{H}_{25} \mathrm{BrN}_{2} \mathrm{O}_{3} \mathrm{~S} \\
(489.43)\end{array}$ & $\begin{array}{l}56.44 \\
56.70\end{array}$ & $\begin{array}{l}5.15 \\
5.02\end{array}$ & $\begin{array}{l}5.72 \\
5.60\end{array}$ \\
\hline $2 \mathrm{f}$ & $\mathrm{H}$ & $\mathrm{NO}_{2}$ & $136-8$ & 92 & 0.21 & 7.32 & $\begin{array}{c}\mathrm{C}_{22} \mathrm{H}_{22} \mathrm{BrN}_{3} \mathrm{O}_{5} \mathrm{~S} \\
(520.4)\end{array}$ & $\begin{array}{l}50.78 \\
50.80\end{array}$ & $\begin{array}{l}4.26 \\
4.30 \\
\end{array}$ & $\begin{array}{l}8.07 \\
7.97 \\
\end{array}$ \\
\hline $2 \mathrm{~g}$ & $\mathrm{Br}$ & $\mathrm{H}$ & 185 & 93 & 0.39 & 6.99 & $\begin{array}{c}\mathrm{C}_{22} \mathrm{H}_{22} \mathrm{Br}_{2} \mathrm{~N}_{2} \mathrm{O}_{3} \mathrm{~S} \\
(554.29)\end{array}$ & $\begin{array}{l}47.67 \\
47.57\end{array}$ & $\begin{array}{l}4.00 \\
3.82\end{array}$ & $\begin{array}{l}5.05 \\
5.10\end{array}$ \\
\hline $2 h$ & $\mathrm{Br}$ & $\mathrm{Br}$ & 210 & 91 & 0.36 & 9.22 & $\begin{array}{c}\mathrm{C}_{22} \mathrm{H}_{21} \mathrm{Br}_{3} \mathrm{~N}_{2} \mathrm{O}_{3} \mathrm{~S} \\
(633.19)\end{array}$ & $\begin{array}{l}41.73 \\
41.93 \\
\end{array}$ & $\begin{array}{l}3.34 \\
3.29 \\
\end{array}$ & $\begin{array}{l}4.42 \\
4.21 \\
\end{array}$ \\
\hline $2 \mathrm{i}$ & $\mathrm{Br}$ & $\mathrm{Cl}$ & 200 & 90 & 0.36 & 9.07 & $\begin{array}{c}\mathrm{C}_{22} \mathrm{H}_{21} \mathrm{Br}_{2} \mathrm{ClN}_{2} \mathrm{O}_{3} \mathrm{~S} \\
(588.74)\end{array}$ & $\begin{array}{l}44.88 \\
45.10 \\
\end{array}$ & $\begin{array}{l}3.60 \\
3.71 \\
\end{array}$ & $\begin{array}{l}4.76 \\
4.69 \\
\end{array}$ \\
\hline $2 \mathrm{j}$ & $\mathrm{Br}$ & $\mathrm{OCH}_{3}$ & 209 & 93 & 0.43 & 8.50 & $\begin{array}{c}\mathrm{C}_{23} \mathrm{H}_{24} \mathrm{Br}_{2} \mathrm{~N}_{2} \mathrm{O}_{4} \mathrm{~S} \\
(584.32)\end{array}$ & $\begin{array}{l}47.28 \\
47.58 \\
\end{array}$ & $\begin{array}{l}4.14 \\
3.80 \\
\end{array}$ & $\begin{array}{l}4.79 \\
4.68 \\
\end{array}$ \\
\hline $2 k$ & $\mathrm{Br}$ & $\mathrm{CH}_{3}$ & $186-7$ & 90 & 0.43 & 8.78 & $\begin{array}{c}\mathrm{C}_{23} \mathrm{H}_{24} \mathrm{Br}_{2} \mathrm{~N}_{2} \mathrm{O}_{3} \mathrm{~S} \\
(568.32) \\
\end{array}$ & $\begin{array}{l}48.61 \\
48.95 \\
\end{array}$ & $\begin{array}{l}4.26 \\
4.00 \\
\end{array}$ & $\begin{array}{l}4.93 \\
5.14 \\
\end{array}$ \\
\hline 21 & $\mathrm{Br}$ & $\mathrm{NO}_{2}$ & 208 & 92 & 0.25 & 8.18 & $\begin{array}{c}\mathrm{C}_{22} \mathrm{H}_{21} \mathrm{Br}_{2} \mathrm{~N}_{3} \mathrm{O}_{5} \mathrm{~S} \\
(599.29)\end{array}$ & $\begin{array}{l}44.09 \\
44.38\end{array}$ & $\begin{array}{l}3.53 \\
3.19 \\
\end{array}$ & $\begin{array}{l}7.01 \\
7.23 \\
\end{array}$ \\
\hline $2 m$ & $\mathrm{Cl}$ & $\mathrm{H}$ & 175 & 91 & 0.40 & 8.13 & $\begin{array}{c}\mathrm{C}_{22} \mathrm{H}_{22} \mathrm{BrClN}_{2} \mathrm{O}_{3} \mathrm{~S} \\
(509.84)\end{array}$ & $\begin{array}{l}51.83 \\
51.52\end{array}$ & $\begin{array}{l}4.35 \\
4.18 \\
\end{array}$ & $\begin{array}{l}5.49 \\
5.59 \\
\end{array}$ \\
\hline $2 n$ & $\mathrm{Cl}$ & $\mathrm{Br}$ & 197 & 90 & 0.36 & 9.07 & $\begin{array}{c}\mathrm{C}_{22} \mathrm{H}_{21} \mathrm{Br}_{2} \mathrm{ClN}_{2} \mathrm{O}_{3} \mathrm{~S} \\
(588.74)\end{array}$ & $\begin{array}{l}44.88 \\
44.61\end{array}$ & $\begin{array}{l}3.60 \\
3.58\end{array}$ & $\begin{array}{l}4.76 \\
4.81\end{array}$ \\
\hline 20 & $\mathrm{Cl}$ & $\mathrm{Cl}$ & 199 & 92 & 0.34 & 8.92 & $\begin{array}{c}\mathrm{C}_{22} \mathrm{H}_{21} \mathrm{BrCl}_{2} \mathrm{~N}_{2} \mathrm{O}_{3} \mathrm{~S} \\
(544.29)\end{array}$ & $\begin{array}{l}48.55 \\
48.60\end{array}$ & $\begin{array}{l}3.89 \\
3.90\end{array}$ & $\begin{array}{l}5.15 \\
5.10\end{array}$ \\
\hline $2 p$ & $\mathrm{Cl}$ & $\mathrm{OCH}_{3}$ & 197 & 88 & 0.45 & 8.35 & $\begin{array}{c}\mathrm{C}_{23} \mathrm{H}_{24} \mathrm{BrClN}_{2} \mathrm{O}_{4} \mathrm{~S} \\
(539.87)\end{array}$ & $\begin{array}{l}51.17 \\
50.93\end{array}$ & $\begin{array}{l}4.48 \\
4.40\end{array}$ & $\begin{array}{l}5.19 \\
5.31\end{array}$ \\
\hline $2 q$ & $\mathrm{Cl}$ & $\mathrm{CH}_{3}$ & 180 & 89 & 0.48 & 8.63 & $\begin{array}{c}\mathrm{C}_{23} \mathrm{H}_{24} \mathrm{BrClN}_{2} \mathrm{O}_{3} \mathrm{~S} \\
(523.87)\end{array}$ & $\begin{array}{l}52.73 \\
52.59 \\
\end{array}$ & $\begin{array}{l}4.62 \\
4.30 \\
\end{array}$ & $\begin{array}{l}5.35 \\
5.24 \\
\end{array}$ \\
\hline $2 r$ & $\mathrm{Cl}$ & $\mathrm{NO}_{2}$ & 199 & 93 & 0.36 & 8.04 & $\begin{array}{c}\mathrm{C}_{22} \mathrm{H}_{21} \mathrm{BrClN}_{3} \mathrm{O}_{5} \mathrm{~S} \\
(554.84)\end{array}$ & $\begin{array}{l}47.62 \\
47.29\end{array}$ & $\begin{array}{l}3.81 \\
4.00\end{array}$ & $\begin{array}{l}7.57 \\
7.53 \\
\end{array}$ \\
\hline $2 \mathrm{~s}$ & $\mathrm{CH}_{3}$ & $\mathrm{H}$ & $186-7$ & 91 & 0.32 & 7.92 & $\begin{array}{c}\mathrm{C}_{23} \mathrm{H}_{25} \mathrm{BrN}_{2} \mathrm{O}_{3} \mathrm{~S} \\
(489.43)\end{array}$ & $\begin{array}{l}56.44 \\
56.70 \\
\end{array}$ & $\begin{array}{l}5.15 \\
5.30 \\
\end{array}$ & $\begin{array}{l}5.72 \\
5.77 \\
\end{array}$ \\
\hline $2 t$ & $\mathrm{CH}_{3}$ & $\mathrm{Br}$ & 188 & 90 & 0.30 & 8.85 & $\begin{array}{c}\mathrm{C}_{23} \mathrm{H}_{24} \mathrm{Br}_{2} \mathrm{~N}_{2} \mathrm{O}_{3} \mathrm{~S} \\
(568.32)\end{array}$ & $\begin{array}{l}48.61 \\
48.82\end{array}$ & $\begin{array}{l}4.26 \\
4.37\end{array}$ & $\begin{array}{l}4.93 \\
4.88\end{array}$ \\
\hline $2 u$ & $\mathrm{CH}_{3}$ & $\mathrm{Cl}$ & $187-8$ & 92 & 0.30 & 8.70 & $\begin{array}{c}\mathrm{C}_{23} \mathrm{H}_{24} \mathrm{BrClN}_{2} \mathrm{O}_{3} \mathrm{~S} \\
(523.87)\end{array}$ & $\begin{array}{l}52.73 \\
53.00\end{array}$ & $\begin{array}{l}4.62 \\
4.60\end{array}$ & $\begin{array}{l}5.35 \\
5.14\end{array}$ \\
\hline $2 v$ & $\mathrm{CH}_{3}$ & $\mathrm{OCH}_{3}$ & 198 & 90 & 0.38 & 8.14 & $\begin{array}{c}\mathrm{C}_{24} \mathrm{H}_{27} \mathrm{BrN}_{2} \mathrm{O}_{4} \mathrm{~S} \\
(519.45)\end{array}$ & $\begin{array}{l}55.49 \\
55.81\end{array}$ & $\begin{array}{l}5.24 \\
5.42\end{array}$ & $\begin{array}{l}5.39 \\
5.53\end{array}$ \\
\hline $2 w$ & $\mathrm{CH}_{3}$ & $\mathrm{CH}_{3}$ & 197 & 88 & 0.36 & 8.42 & $\begin{array}{c}\mathrm{C}_{24} \mathrm{H}_{27} \mathrm{BrN}_{2} \mathrm{O}_{3} \mathrm{~S} \\
(503.45)\end{array}$ & $\begin{array}{l}57.26 \\
57.52\end{array}$ & $\begin{array}{l}5.41 \\
5.63\end{array}$ & $\begin{array}{l}5.56 \\
5.67\end{array}$ \\
\hline $2 x$ & $\mathrm{CH}_{3}$ & $\mathrm{NO}_{2}$ & $198-9$ & 85 & 0.21 & 7.82 & $\begin{array}{c}\mathrm{C}_{23} \mathrm{H}_{24} \mathrm{BrN}_{3} \mathrm{O}_{5} \mathrm{~S} \\
(534.42)\end{array}$ & $\begin{array}{l}51.69 \\
52.00\end{array}$ & $\begin{array}{l}4.53 \\
4.61\end{array}$ & $\begin{array}{l}7.86 \\
8.00\end{array}$ \\
\hline
\end{tabular}

$*=10 \%$ Acetone $/ \mathrm{CHCl}_{3}$ 
Table II: The antibacterial activity [zones of inhibition (mm) at concentration $100 \mu \mathrm{mol} / \mathrm{mL}$ ] of compounds (2a-x) and Chloramphenicol.

\begin{tabular}{|c|c|c|c|c|c|}
\hline No. & $\begin{array}{c}\text { Staphylococcus } \\
\text { aureus }\end{array}$ & $\begin{array}{c}\text { Bacillus } \\
\text { cereus }\end{array}$ & $\begin{array}{c}\text { Escherichia } \\
\text { coli }\end{array}$ & $\begin{array}{c}\text { Pseudomonas } \\
\text { aeruginosa }\end{array}$ & $\begin{array}{c}\text { Serratia } \\
\text { marcescens }\end{array}$ \\
\hline $\mathbf{2 a}$ & - & - & - & - & - \\
\hline $2 \mathrm{~b}$ & 21 & - & - & - & - \\
\hline $2 \mathrm{c}$ & - & 16 & - & - & - \\
\hline $2 d$ & - & - & - & - & 18 \\
\hline $2 e$ & 22 & - & - & 20 & 19 \\
\hline $2 f$ & - & 19 & - & - & - \\
\hline$\square \mathbf{g}$ & - & 14 & - & - & - \\
\hline $2 \mathrm{~h}$ & - & 13 & 21 & - & - \\
\hline $2 \mathbf{i}$ & - & 15 & 21 & 17 pi & 20 \\
\hline $2 \mathrm{j}$ & - & 22 & 22 & 20 & 17 \\
\hline $2 \mathrm{k}$ & 18 & 14 & 18 & 19 & - \\
\hline 21 & 21 & 25 & 21 & 20 & - \\
\hline $2 \mathrm{~m}$ & 14 & - & - & - & - \\
\hline $2 n$ & 23 & 16 & 22 & 21 & 18 \\
\hline 20 & 19 & 18 & 21 & 20 & 17 \\
\hline $2 p$ & 16 & 23 & - & 16 & 13 \\
\hline $2 q$ & 21 & 23 & - & - & 17 \\
\hline $2 r$ & 21 & 18 & 20 & 21 & 14 \\
\hline $2 s$ & - & - & - & - & - \\
\hline $2 t$ & - & 14 & 23 & - & - \\
\hline $2 u$ & - & 14 & 16 & - & - \\
\hline $2 v$ & - & - & - & - & - \\
\hline $2 w$ & 14 & - & - & - & - \\
\hline $2 x$ & 22 & - & - & 20 & 14 \\
\hline CHL & 27 & 32 & 30 & 24 & 41 \\
\hline
\end{tabular}

$\mathrm{Pi}=$ partial inhibition

$\mathrm{CHL}=$ Chloramphenicol
- = no inhibition

AUMC = Assiut University Mycological Center 
Table III: The antibacterial activity [zones of inhibition $(\mathrm{mm})$ and a serial dilution $(\mu \mathrm{mol})$ ] of compounds (2a-x) and Chloramphenicol.

\begin{tabular}{|c|c|c|c|c|c|c|}
\hline No. & $\begin{array}{c}\text { Conc. } \\
\mu \mathrm{mol} / \mathrm{mL}\end{array}$ & $\begin{array}{c}\text { Staphylococcus } \\
\text { aureus }\end{array}$ & $\begin{array}{c}\text { Bacillus } \\
\text { cereus }\end{array}$ & $\begin{array}{c}\text { Escherichia } \\
\text { coli }\end{array}$ & $\begin{array}{c}\text { Pseudomonas } \\
\text { aeruginosa }\end{array}$ & $\begin{array}{c}\text { Serratia } \\
\text { marcescens }\end{array}$ \\
\hline \multirow{4}{*}{$2 b$} & 50 & 16 & 0 & 0 & 0 & 0 \\
\hline & 25 & 14 & - & - & - & - \\
\hline & 12.5 & 12 & - & - & - & - \\
\hline & 6.25 & 0 & - & - & - & - \\
\hline $2 \mathrm{c}$ & 50 & 0 & 0 & 0 & 0 & 0 \\
\hline \multirow{5}{*}{$2 d$} & 50 & - & - & - & - & 21 \\
\hline & 25 & - & - & - & - & 18 \\
\hline & 12.5 & - & - & - & - & 13 \\
\hline & 6.25 & - & - & - & - & 12 \\
\hline & 3.125 & - & - & - & - & 0 \\
\hline \multirow{6}{*}{$2 e$} & 50 & 17 & 0 & 0 & 20 & 13 \\
\hline & 25 & 13 & - & - & 17 & 10 \\
\hline & 12.5 & 12 & - & - & 12 & 8 \\
\hline & 6.25 & 10 & - & - & 10 & 0 \\
\hline & 3.125 & 8 & - & - & 0 & - \\
\hline & 1.56 & 0 & - & - & - & - \\
\hline \multirow{4}{*}{$2 f$} & 50 & 0 & 18 & 0 & 0 & 0 \\
\hline & 25 & - & 14 & - & - & - \\
\hline & 12.5 & - & 12 & - & - & - \\
\hline & 6.25 & - & 0 & - & - & - \\
\hline $2 \mathrm{~g}$ & 50 & 0 & 0 & 0 & 0 & 0 \\
\hline \multirow{5}{*}{$2 h$} & 50 & - & 0 & 18 & - & - \\
\hline & 25 & - & - & 16 & - & - \\
\hline & 12.5 & - & - & 13 & - & - \\
\hline & 6.25 & - & - & 10 & - & - \\
\hline & 3.125 & - & - & 0 & - & - \\
\hline \multirow{5}{*}{$2 \mathbf{i}$} & 50 & 0 & 0 & 18 & 0 & 12 \\
\hline & 25 & - & - & 15 & & 0 \\
\hline & 12.5 & - & - & 13 & - & - \\
\hline & 6.25 & - & - & 12 & - & - \\
\hline & 3.125 & - & - & 0 & - & - \\
\hline \multirow{4}{*}{$2 \mathbf{j}$} & 50 & 0 & 23 & 23 & 18 & 14 \\
\hline & 25 & - & 18 & 18 & 15 & 12 \\
\hline & 12.5 & - & 16 & 16 & 12 & 0 \\
\hline & 6.25 & - & 0 & 0 & 0 & - \\
\hline \multirow{7}{*}{$2 k$} & 50 & 22 & 14 & 19 & 16 & 0 \\
\hline & 25 & 17 & 0 & 16 & 15 & - \\
\hline & 12.5 & 14 & - & 14 & 13 & - \\
\hline & 6.25 & 12 & - & 12 & 0 & - \\
\hline & 3.125 & 11 & - & 0 & - & - \\
\hline & 1.56 & 10 & - & - & - & - \\
\hline & 0.78 & 0 & - & - & - & - \\
\hline \multirow{5}{*}{21} & 50 & 17 & 22 & 21 & 19 & 0 \\
\hline & 25 & 14 & 18 & 16 & 17 & - \\
\hline & 12.5 & 12 & 14 & 12 & 13 & - \\
\hline & 6.25 & 9 & 10 & 10 & 10 & - \\
\hline & 3.125 & 0 & 0 & 0 & 0 & - \\
\hline $2 \mathrm{~m}$ & 50 & 0 & - & - & - & - \\
\hline \multirow{9}{*}{$2 n$} & 50 & 20 & 10 & 18 & 22 & 17 \\
\hline & 25 & 15 & 0 & 15 & 18 & 12 \\
\hline & 12.5 & 13 & - & 12 & 15 & 10 \\
\hline & 6.25 & 10 & - & 10 & 13 & 0 \\
\hline & 3.125 & 10 & - & 0 & 0 & - \\
\hline & 1.56 & 10 & - & - & - & - \\
\hline & 0.78 & 8 & - & - & - & - \\
\hline & 0.39 & 8 & - & - & - & - \\
\hline & 0.19 & 0 & - & - & - & - \\
\hline
\end{tabular}


Table III: Continued.

\begin{tabular}{|c|c|c|c|c|c|c|}
\hline No. & $\begin{array}{c}\text { Conc. } \\
\mu \mathrm{mol} / \mathrm{mL}\end{array}$ & $\begin{array}{c}\text { Staphylococcus } \\
\text { aureus }\end{array}$ & $\begin{array}{c}\text { Bacillus } \\
\text { cereus }\end{array}$ & $\begin{array}{c}\text { Escherichia } \\
\text { coli }\end{array}$ & $\begin{array}{c}\text { Pseudomonas } \\
\text { aeruginosa }\end{array}$ & $\begin{array}{c}\text { Serratia } \\
\text { marcescens }\end{array}$ \\
\hline \multirow{5}{*}{20} & 50 & 17 & 0 & 17 & 21 & 16 \\
\hline & 25 & 14 & - & 14 & 16 & 12 \\
\hline & 12.5 & 12 & - & 12 & 14 & 10 \\
\hline & 6.25 & 10 & - & 0 & 11 & 0 \\
\hline & 3.125 & 0 & - & - & 0 & - \\
\hline \multirow{7}{*}{$2 p$} & 50 & 14 & 22 & 0 & 15 & 0 \\
\hline & 25 & 12 & 18 & - & 13 & - \\
\hline & 12.5 & 10 & 14 & - & 10 & - \\
\hline & 6.25 & 10 & 12 & - & 10 & - \\
\hline & 3.125 & 8 & 0 & - & 0 & - \\
\hline & 1.56 & 8 & - & - & - & - \\
\hline & 0.78 & 0 & - & - & - & - \\
\hline \multirow{8}{*}{$2 q$} & 50 & 18 & 18 & 0 & 0 & 17 \\
\hline & 25 & 13 & 13 & - & - & 12 \\
\hline & 12.5 & 12 & 0 & - & - & 10 \\
\hline & 6.25 & 11 & - & - & - & 0 \\
\hline & 3.125 & 11 & - & - & - & - \\
\hline & 1.56 & 10 & - & - & - & - \\
\hline & 0.78 & 10 & - & - & - & - \\
\hline & 0.39 & 0 & - & - & - & - \\
\hline \multirow{7}{*}{$2 r$} & 50 & 18 & 14 & 18 & 20 & 13 \\
\hline & 25 & 14 & 0 & 17 & 16 & 12 \\
\hline & 12.5 & 12 & - & 12 & 14 & 0 \\
\hline & 6.25 & 11 & - & 10 & 12 & - \\
\hline & 3.125 & 10 & - & 0 & 0 & - \\
\hline & 1.56 & 10 & - & - & - & - \\
\hline & 0.78 & 0 & - & - & - & - \\
\hline \multirow{5}{*}{$2 t$} & 50 & 0 & 0 & 22 & 0 & 0 \\
\hline & 25 & - & - & 15 & - & - \\
\hline & 12.5 & - & - & 13 & - & - \\
\hline & 6.25 & - & - & 12 & - & - \\
\hline & 3.125 & - & - & 0 & - & - \\
\hline \multirow{4}{*}{$2 u$} & 50 & 0 & 12 & 17 & 0 & 0 \\
\hline & 25 & - & 0 & 12 & - & - \\
\hline & 12.5 & - & - & 10 & - & - \\
\hline & 6.25 & - & - & 0 & - & - \\
\hline \multirow{3}{*}{$2 w$} & 50 & 12 & 0 & 0 & 0 & 0 \\
\hline & 25 & 8 & - & - & - & - \\
\hline & 12.5 & 0 & - & - & - & - \\
\hline \multirow{6}{*}{$2 x$} & 50 & 17 & 0 & 0 & 15 & 16 \\
\hline & 25 & 14 & - & - & 12 & 10 \\
\hline & 12.5 & 12 & - & - & 8 & 0 \\
\hline & 6.25 & 10 & - & - & 0 & - \\
\hline & 3.125 & 8 & - & - & - & - \\
\hline & 1.56 & 0 & - & - & - & - \\
\hline \multirow{8}{*}{ CHL } & 10 & 17 & 32 & 26 & 16 & 40 \\
\hline & 5 & 17 & 32 & 26 & 14 & 38 \\
\hline & 2.5 & 15 & 30 & 20 & 12 & 34 \\
\hline & 1.25 & 13 & 28 & 16 & 12 & 28 \\
\hline & 0.6 & 12 & 25 & 14 & 10 & 26 \\
\hline & 0.3 & 10 & 18 & 12 & 10 & 20 \\
\hline & 0.15 & 10 & 16 & 0 & 10 & - \\
\hline & 0.08 & 0 & 0 & - & - & - \\
\hline
\end{tabular}


Table IV: Antibacterial activity [inhibition zone in mm and MICs (in $\mu$ mol) given in brackets] of compounds (2a-x) and Chloramphenicol.

\begin{tabular}{||c|c|c|c|c|c||}
\hline No. & $\begin{array}{c}\text { Staphylococcus } \\
\text { aureus }\end{array}$ & $\begin{array}{c}\text { Bacillus } \\
\text { cereus }\end{array}$ & $\begin{array}{c}\text { Escherichia } \\
\text { coli }\end{array}$ & $\begin{array}{c}\text { Pseudomonas } \\
\text { aeruginosa }\end{array}$ & $\begin{array}{c}\text { Serratia } \\
\text { marcescens }\end{array}$ \\
\hline $\mathbf{2 a}$ & - & - & - & - & - \\
\hline $\mathbf{2 b}$ & $12(12.5)$ & - & - & - & - \\
\hline $\mathbf{2 c}$ & - & $16(100)$ & - & - & - \\
\hline $\mathbf{2 d}$ & - & - & - & - & $12(6.25)$ \\
\hline $\mathbf{2 e}$ & $8(3.125)$ & - & - & $10(6.25)$ & $8(12.5)$ \\
\hline $\mathbf{2 f}$ & - & $12(12.5)$ & - & - & - \\
\hline $\mathbf{2 g}$ & - & $14(100)$ & - & - & - \\
\hline $\mathbf{2 h}$ & - & $13(100)$ & $10(6.25)$ & - & - \\
\hline $\mathbf{2 i}$ & - & $15(100)$ & $12(6.25)$ & $17 p . i(100)$ & $12(50)$ \\
\hline $\mathbf{2 j}$ & - & $16(12.5)$ & $12(12.5)$ & $12(25)$ & - \\
\hline $\mathbf{2 k}$ & $10(1.56)$ & $14(50)$ & $12(6.25)$ & $13(12.5)$ & - \\
\hline $\mathbf{2}$ & $9(6.25)$ & $10(6.25)$ & $10(6.25)$ & $10(6.25)$ & - \\
\hline $\mathbf{2 m}$ & $14(100)$ & - & - & - & - \\
\hline $\mathbf{2 n}$ & $8(0.39)$ & $10(50)$ & $10(6.25)$ & $13(6.25)$ & $10(12.5)$ \\
\hline $\mathbf{2 0}$ & $10(6.25)$ & $18(100)$ & $12(12.5)$ & $11(6.25)$ & $10(12.5)$ \\
\hline $\mathbf{2 p}$ & $8(1.56)$ & $12(6.25)$ & - & $10(6.25)$ & $13(100)$ \\
\hline $\mathbf{2 q}$ & $10(0.78)$ & $13(25)$ & - & - & $10(12.5)$ \\
\hline $\mathbf{2 r}$ & $10(1.56)$ & $14(50)$ & $10(6.25)$ & $12(6.25)$ & $12(25)$ \\
\hline $\mathbf{2} \mathbf{2}$ & - & - & - & - & - \\
\hline $\mathbf{2 t}$ & - & $14(100)$ & $12(6.25)$ & - & - \\
\hline $\mathbf{2 u}$ & - & $12(50)$ & $10(12.5)$ & - & - \\
\hline $\mathbf{2 v}$ & - & - & - & - & - \\
\hline $\mathbf{2 w}$ & $8(25)$ & - & - & - & - \\
\hline $\mathbf{2 x}$ & $8(3.125)$ & - & - & $8(12.5)$ & $10(25)$ \\
\hline $\mathbf{C H L}$ & $10(0.15)$ & $16(0.15)$ & $12(0.3)$ & $10(0.15)$ & $20(0.3)$ \\
\hline & & & & & \\
\hline
\end{tabular}

Table V: The antifungal zones of inhibition ( $\mathrm{mm}$ ) of compounds (2a-x) and Clotrimazole.

\begin{tabular}{|c|c|c|c|c|c|c||}
\hline No. & $\begin{array}{c}\text { Candida } \\
\text { albicans }\end{array}$ & $\begin{array}{c}\text { Geotrichum } \\
\text { candidum }\end{array}$ & $\begin{array}{c}\text { Fusarium } \\
\text { oxysporum }\end{array}$ & $\begin{array}{c}\text { Aspergillus } \\
\text { flavus }\end{array}$ & $\begin{array}{c}\text { Trichophyton } \\
\text { rubrum }\end{array}$ & $\begin{array}{c}\text { Scopulariopsis } \\
\text { brevicaulis }\end{array}$ \\
\hline $\mathbf{2 a}$ & - & 14 & 22 & - & 12 & - \\
\hline $\mathbf{2 b}$ & 22 & 22 & 20 & - & 32 & - \\
\hline $\mathbf{2 c}$ & 22 & 24 & - & - & 32 & - \\
\hline $\mathbf{2 d}$ & 20 & 19 & - & - & 16 & - \\
\hline $\mathbf{2 e}$ & 16 & 13 & - & - & 18 & - \\
\hline $\mathbf{2 f}$ & 19 & 14 & 12 & 15 & 17 & 16 \\
\hline $\mathbf{2 g}$ & - & 20 & 8 & - & 24 & - \\
\hline $\mathbf{2 h}$ & 24 & 20 & - & - & 34 & - \\
\hline $\mathbf{2 i}$ & 21 & 20 & - & - & 32 & - \\
\hline $\mathbf{2 j}$ & 19 & 10 & - & - & 20 & - \\
\hline $\mathbf{2 k}$ & 20 & 18 & - & - & 25 & - \\
\hline $\mathbf{2 l}$ & - & 14 & - & - & 20 & - \\
\hline $\mathbf{2 m}$ & 18 & 18 & - & - & 23 & - \\
\hline $\mathbf{2 n}$ & 22 & 23 & - & - & 32 & - \\
\hline $\mathbf{2 0}$ & 12 & 22 & - & - & 14 & - \\
\hline $\mathbf{2 p}$ & 19 & - & - & - & 25 & - \\
\hline $\mathbf{2 q}$ & 16 & 17 & 8 & - & 23 & - \\
\hline $\mathbf{2 r}$ & - & 17 & 8 & - & 20 & - \\
\hline $\mathbf{2} \mathbf{2}$ & - & 18 & - & - & 25 & - \\
\hline $\mathbf{2 t}$ & 18 & 23 & - & - & 33 & - \\
\hline $\mathbf{2 u}$ & - & 14 & - & - & 31 & - \\
\hline $\mathbf{2 v}$ & - & 16 & - & - & 16 & - \\
\hline $\mathbf{2} \mathbf{2}$ & - & - & - & - & 25 & - \\
\hline $\mathbf{2 x}$ & - & 17 & - & - & 16 & - \\
\hline $\mathbf{C L O}$ & 30 & 24 & 22 & 27 & 35 & 26 \\
\hline \hline
\end{tabular}

$\mathrm{CLO}=$ Clotrimazole 
Table VI: The antifungal activity [zones of inhibition $(\mathrm{mm})$ and a series of descending concentrations $(\mu \mathrm{mol})]$ of compounds (2a-x) and clotrimazole.

\begin{tabular}{|c|c|c|c|c|c|c|c|}
\hline No. & $\begin{array}{c}\text { Conc. } \\
\mu \mathrm{mol} / \mathrm{mL}\end{array}$ & $\begin{array}{l}\text { Candida } \\
\text { albicans }\end{array}$ & $\begin{array}{l}\text { Geotrichum } \\
\text { candidum }\end{array}$ & $\begin{array}{l}\text { Fusarium } \\
\text { oxysporum }\end{array}$ & $\begin{array}{c}\text { Aspergillus } \\
\text { flavus }\end{array}$ & $\begin{array}{c}\text { Trichophyton } \\
\text { rubrum }\end{array}$ & $\begin{array}{c}\text { Scopulariopsis } \\
\text { brevicaulis }\end{array}$ \\
\hline \multirow{5}{*}{$\mathbf{2 a}$} & 50 & 0 & 11 & 17 & 0 & 16 & 0 \\
\hline & 25 & - & 11 & 16 & - & 12 & - \\
\hline & 12.5 & - & 0 & 12 & - & 0 & - \\
\hline & 6.25 & - & - & 10 & - & - & - \\
\hline & 3.125 & - & - & 0 & - & - & - \\
\hline \multirow{5}{*}{$2 b$} & 50 & 0 & 16 & 13 & 0 & 26 & 0 \\
\hline & 25 & - & 12 & 12 & - & 22 & - \\
\hline & 12.5 & - & 10 & 8 & - & 18 & - \\
\hline & 6.25 & - & 10 & 0 & - & 14 & - \\
\hline & 3.125 & - & 0 & - & - & 0 & - \\
\hline \multirow{5}{*}{$2 c$} & 50 & 23 & 14 & 0 & 0 & 28 & 0 \\
\hline & 25 & 18 & 13 & - & - & 23 & - \\
\hline & 12.5 & 12 & 12 & - & - & 17 & - \\
\hline & 6.25 & 0 & 12 & - & - & - & - \\
\hline & 3.125 & - & 0 & - & - & - & - \\
\hline \multirow{7}{*}{$2 d$} & 50 & 17 & 16 & 0 & 0 & 15 & 0 \\
\hline & 25 & 12 & 13 & - & - & 10 & - \\
\hline & 12.5 & 10 & 11 & - & - & 0 & - \\
\hline & 6.25 & 0 & 10 & - & - & - & - \\
\hline & 3.125 & - & 10 & - & - & - & - \\
\hline & 1.56 & - & 8 & - & - & - & - \\
\hline & 0.78 & - & 0 & - & - & - & - \\
\hline \multirow{4}{*}{$2 e$} & 50 & 0 & 14 & 0 & 0 & 17 & 0 \\
\hline & 25 & - & 12 & - & - & 11 & - \\
\hline & 12.5 & - & 11 & - & - & 0 & - \\
\hline & 6.25 & - & 0 & - & - & - & - \\
\hline \multirow{5}{*}{$2 f$} & 50 & 16 & 14 & 10 & 12 & 14 & 17 \\
\hline & 25 & 14 & 13 & 0 & 0 & 10 & 13 \\
\hline & 12.5 & 0 & 10 & - & - & 0 & 0 \\
\hline & 6.25 & -- & 0 & - & - & - & - \\
\hline & 3.125 & - & - & - & - & - & - \\
\hline \multirow{6}{*}{$2 \mathrm{~g}$} & 50 & 0 & 15 & 0 & 0 & 22 & 0 \\
\hline & 25 & - & 13 & - & - & 18 & - \\
\hline & 12.5 & - & 11 & - & - & 12 & - \\
\hline & 6.25 & - & 11 & - & - & 10 & - \\
\hline & 3.125 & - & 10 & - & - & 0 & - \\
\hline & 1.56 & - & 0 & - & - & & - \\
\hline \multirow{6}{*}{$2 h$} & 50 & 20 & 18 & 0 & 0 & 30 & 0 \\
\hline & 25 & 16 & 15 & - & - & 28 & - \\
\hline & 12.5 & 10 & 12 & - & - & 20 & - \\
\hline & 6.25 & 8 & 10 & - & - & 14 & - \\
\hline & 3.125 & 0 & 9 & - & - & 0 & - \\
\hline & 1.56 & - & 0 & - & - & & - \\
\hline \multirow{5}{*}{$2 \mathbf{i}$} & 50 & 18 & 16 & 0 & 0 & 28 & 0 \\
\hline & 25 & 14 & 13 & - & - & 22 & - \\
\hline & 12.5 & 13 & 13 & - & - & 15 & - \\
\hline & 6.25 & 0 & 12 & - & - & 13 & - \\
\hline & 3.125 & - & 0 & - & - & 0 & - \\
\hline \multirow{5}{*}{$2 \mathbf{j}$} & 50 & 16 & 14 & 0 & 0 & 20 & 0 \\
\hline & 25 & 14 & 12 & - & - & 18 & - \\
\hline & 12.5 & 10 & 10 & - & - & 14 & - \\
\hline & 6.25 & 0 & 8 & - & - & 10 & - \\
\hline & 3.125 & & 0 & - & - & 0 & - \\
\hline \multirow[t]{3}{*}{$2 \mathrm{k}$} & 50 & 16 & 16 & 0 & 0 & 26 & 0 \\
\hline & 25 & 16 & 14 & - & - & 22 & - \\
\hline & 12.5 & 12 & 13 & - & - & 12 & - \\
\hline
\end{tabular}


Table VI: Continued.

\begin{tabular}{|c|c|c|c|c|c|c|c|}
\hline No. & $\begin{array}{c}\text { Conc. } \\
\mu \mathrm{mol} / \mathrm{mL}\end{array}$ & $\begin{array}{l}\text { Candida } \\
\text { albicans }\end{array}$ & $\begin{array}{c}\text { Geotrichum } \\
\text { candidum }\end{array}$ & $\begin{array}{c}\text { Fusarium } \\
\text { oxysporum }\end{array}$ & $\begin{array}{l}\text { Aspergillus } \\
\text { flavus }\end{array}$ & $\begin{array}{l}\text { Trichophyton } \\
\text { rubrum }\end{array}$ & $\begin{array}{c}\text { Scopulariopsis } \\
\text { brevicaulis }\end{array}$ \\
\hline & 6.25 & 0 & 12 & - & - & 8 & - \\
\hline & 3.125 & - & 0 & - & - & 0 & - \\
\hline \multirow{4}{*}{21} & 50 & 0 & 14 & 0 & 0 & 16 & 0 \\
\hline & 25 & - & 12 & - & - & 13 & - \\
\hline & 12.5 & - & 10 & - & - & 0 & - \\
\hline & 6.25 & - & 0 & - & - & & - \\
\hline \multirow{6}{*}{$2 m$} & 50 & 20 & 14 & 0 & 0 & 22 & 0 \\
\hline & 25 & 18 & 14 & - & - & 20 & - \\
\hline & 12.5 & 12 & 12 & - & - & 14 & - \\
\hline & 6.25 & 0 & 10 & - & - & 10 & - \\
\hline & 3.125 & - & 10 & - & - & 0 & - \\
\hline & 1.56 & - & 0 & - & - & & - \\
\hline \multirow{6}{*}{$2 n$} & 50 & 22 & 18 & 0 & 0 & 33 & 0 \\
\hline & 25 & 18 & 16 & - & - & 30 & - \\
\hline & 12.5 & 16 & 12 & - & - & 22 & - \\
\hline & 6.25 & 12 & 12 & - & - & 20 & - \\
\hline & 3.125 & 0 & 0 & - & - & 18 & - \\
\hline & 1.56 & - & - & - & - & 0 & - \\
\hline \multirow{4}{*}{20} & 50 & 0 & 16 & 0 & 0 & 0 & 0 \\
\hline & 25 & - & 12 & - & - & - & - \\
\hline & 12.5 & - & 12 & - & - & - & - \\
\hline & 6.25 & - & 0 & - & - & - & - \\
\hline \multirow{5}{*}{$2 p$} & 50 & 18 & 0 & 0 & 0 & 30 & 0 \\
\hline & 25 & 16 & - & - & - & 25 & - \\
\hline & 12.5 & 10 & - & - & - & 18 & - \\
\hline & 6.25 & 0 & - & - & - & 13 & - \\
\hline & 3.125 & - & - & - & - & 0 & - \\
\hline \multirow{5}{*}{$2 q$} & 50 & 17 & 16 & 0 & 0 & 24 & 0 \\
\hline & 25 & 14 & 13 & - & - & 20 & - \\
\hline & 12.5 & 0 & 13 & - & - & 14 & - \\
\hline & 6.25 & - & 12 & - & - & 0 & - \\
\hline & 3.125 & - & 0 & - & - & - & - \\
\hline \multirow{5}{*}{$2 \mathbf{r}$} & 50 & 0 & 14 & 0 & 0 & 14 & 0 \\
\hline & 25 & - & 12 & - & - & 10 & - \\
\hline & 12.5 & - & 11 & - & - & 0 & - \\
\hline & 6.25 & - & 8 & - & - & - & - \\
\hline & 3.125 & - & 0 & - & - & - & - \\
\hline \multirow{5}{*}{$2 s$} & 50 & 0 & 14 & 0 & 0 & 25 & 0 \\
\hline & 25 & - & 12 & - & - & 17 & - \\
\hline & 12.5 & - & 11 & - & - & 10 & - \\
\hline & 6.25 & - & 10 & - & - & 0 & - \\
\hline & 3.125 & - & 0 & - & - & - & - \\
\hline \multirow{8}{*}{$2 t$} & 50 & 16 & 16 & 0 & 0 & 28 & 0 \\
\hline & 25 & 12 & 13 & - & - & 20 & - \\
\hline & 12.5 & 10 & 12 & - & - & 18 & - \\
\hline & 6.25 & 0 & 12 & - & - & 14 & - \\
\hline & 3.125 & - & 12 & - & - & 10 & - \\
\hline & 1.56 & - & 10 & - & - & 0 & - \\
\hline & 0.78 & - & 8 & - & - & - & - \\
\hline & 0.39 & - & 0 & - & - & - & - \\
\hline \multirow{5}{*}{$2 u$} & 50 & 0 & 0 & 0 & 0 & 25 & 0 \\
\hline & 25 & - & & - & - & 20 & - \\
\hline & 12.5 & - & - & - & - & 15 & - \\
\hline & 6.25 & - & - & - & - & 10 & - \\
\hline & 3.125 & - & - & - & - & 0 & - \\
\hline \multirow{4}{*}{$2 v$} & 50 & 0 & 14 & 0 & 0 & 14 & 0 \\
\hline & 25 & - & 13 & - & - & 10 & - \\
\hline & 12.5 & - & 12 & - & - & 0 & - \\
\hline & 6.25 & - & 12 & - & - & - & - \\
\hline
\end{tabular}


Table VI: Continued.

\begin{tabular}{|c|c|c|c|c|c|c|c|}
\hline No. & $\begin{array}{c}\text { Conc. } \\
\mu \mathrm{mol} / \mathrm{mL}\end{array}$ & $\begin{array}{l}\text { Candida } \\
\text { albicans }\end{array}$ & $\begin{array}{l}\text { Geotrichum } \\
\text { candidum }\end{array}$ & $\begin{array}{l}\text { Fusarium } \\
\text { oxysporum }\end{array}$ & $\begin{array}{l}\text { Aspergillus } \\
\text { flavus }\end{array}$ & $\begin{array}{c}\text { Trichophyton } \\
\text { rubrum }\end{array}$ & $\begin{array}{c}\text { Scopulariopsis } \\
\text { brevicaulis }\end{array}$ \\
\hline & 3.125 & - & 11 & - & - & - & - \\
\hline & 1.56 & - & 11 & - & - & - & - \\
\hline & 0.78 & - & 0 & - & - & - & - \\
\hline \multirow{3}{*}{$2 w$} & 50 & 0 & 0 & 0 & 0 & 23 & 0 \\
\hline & 25 & - & - & - & - & 12 & - \\
\hline & 12.5 & - & - & - & - & 0 & - \\
\hline \multirow{5}{*}{$2 x$} & 50 & 0 & 16 & 0 & 0 & 16 & 0 \\
\hline & 25 & - & 14 & - & - & 0 & - \\
\hline & 12.5 & - & 13 & - & - & - & - \\
\hline & 6.25 & - & 12 & - & - & - & - \\
\hline & 3.125 & - & 0 & - & - & - & - \\
\hline \multirow{6}{*}{ CLO } & 10 & 30 & 22 & 22 & 27 & 34 & 24 \\
\hline & 5 & 30 & 22 & 22 & 27 & 34 & 23 \\
\hline & 2.5 & 26 & 22 & 22 & 25 & 34 & 23 \\
\hline & 1.25 & 26 & 22 & 18 & 25 & 34 & 20 \\
\hline & 0.6 & 26 & 22 & 18 & 25 & 34 & 20 \\
\hline & 0.3 & 26 & 22 & 18 & 25 & 34 & 20 \\
\hline
\end{tabular}

Table VII: Antifungal activity [inhibition zone (mm) and MICs ( $\mu \mathrm{mol})$ given in brackets] of compounds (2a-x) and Clotrimazole.

\begin{tabular}{||c|c|c|c|c|c|c||}
\hline No. & $\begin{array}{c}\text { Candida } \\
\text { albicans }\end{array}$ & $\begin{array}{c}\text { Geotrichum } \\
\text { candidum }\end{array}$ & $\begin{array}{c}\text { Fusarium } \\
\text { oxysporum }\end{array}$ & $\begin{array}{c}\text { Aspergillus } \\
\text { flavus }\end{array}$ & $\begin{array}{c}\text { Trichophyton } \\
\text { rubrum }\end{array}$ & $\begin{array}{c}\text { Scopulariopsis } \\
\text { brevicaulis }\end{array}$ \\
\hline $\mathbf{2 a}$ & - & $11(25)$ & $6(25)$ & - & $12(25)$ & - \\
\hline $\mathbf{2 b}$ & $22(100)$ & $10(6.25)$ & $8(12.5)$ & - & $14(6.25)$ & - \\
\hline $\mathbf{2 c}$ & $12(12.5)$ & $12(6.25)$ & - & - & $17(12.5)$ & - \\
\hline $\mathbf{2 d}$ & $10(12.5)$ & $8(1.56)$ & - & - & $10(25)$ & - \\
\hline $\mathbf{2 e}$ & $16(100)$ & $11(12.5)$ & - & - & $11(25)$ & - \\
\hline $\mathbf{2 f}$ & $14(25)$ & $10(12.5)$ & $10(50)$ & $12(50)$ & $10(25)$ & $13(25)$ \\
\hline $\mathbf{2 g}$ & - & $10(3.125)$ & $8(100)$ & - & $10(6.25)$ & - \\
\hline $\mathbf{2 h}$ & $8(6.25)$ & $9(3.125)$ & - & - & $14(6.25)$ & - \\
\hline $\mathbf{2 i}$ & $13(12.5)$ & $12(6.25)$ & - & - & $13(6.25)$ & - \\
\hline $\mathbf{2 j}$ & $10(12.5)$ & $8(6.25)$ & - & - & $10(6.25)$ & - \\
\hline $\mathbf{2 k}$ & $12(12.5)$ & $12(6.25)$ & - & - & $8(6.25)$ & - \\
\hline $\mathbf{2 l}$ & - & $10(12.5)$ & - & - & $13(25)$ & - \\
\hline $\mathbf{2 m}$ & $12(12.5)$ & $10(3.125)$ & - & - & $10(6.25)$ & - \\
\hline $\mathbf{2 n}$ & $12(6.25)$ & $12(6.25)$ & - & - & $18(3.125)$ & - \\
\hline $\mathbf{2 0}$ & $12(100)$ & $12(12.5)$ & - & - & $14(100)$ & - \\
\hline $\mathbf{2 p}$ & $10(12.5)$ & - & - & - & $13(6.25)$ & - \\
\hline $\mathbf{2 q}$ & $14(25)$ & $12(6.25)$ & $8(100)$ & - & $14(12.5)$ & - \\
\hline $\mathbf{2 r}$ & - & $8(6.25)$ & $8(100)$ & - & $10(25)$ & - \\
\hline $\mathbf{2 s}$ & - & $10(6.25)$ & - & - & $10(6.25)$ & - \\
\hline $\mathbf{2 t}$ & $10(12.5)$ & $8(0.78)$ & - & - & $10(12.5)$ & - \\
\hline $\mathbf{2 u}$ & - & $14(100)$ & - & - & $10(6.25)$ & - \\
\hline $\mathbf{2 v}$ & - & $11(1.56)$ & - & - & $10(25)$ & - \\
\hline $\mathbf{2 w}$ & - & - & - & - & $12(25)$ & - \\
\hline $\mathbf{2 x}$ & - & $12(6.25)$ & - & - & $16(50)$ & - \\
\hline CLO & $26(0.3)$ & $22(0.3)$ & $8(0.3)$ & $25(0.3)$ & $34(0.3)$ & $20(0.3)$ \\
\hline
\end{tabular}




\section{REFERENCES}

1- F. C. Tenover, The American Journal of Medicine, 119 (6A), S3-S10 (2006).

2- E. Silva, J. A. Díaz, M. J. Arias, A. P. Hernández, de la Torre, A. Silva, et al., BMC Clin Pharmacol., 10, 3 (2010).

3- M. M. Ghorab, Y. A. Mohamed, S. A. Mohamed and Y. A. Ammar, Phosphorus, Sulfur Silicon Relat. Elem. 108, 249 (1996), through Chem. Abs., 125, 195563 (1996).

4- M. M. Ghorab, S. M. Abdel-Gawad and M. S. A. El-Gaby, Il Farmaco, 55, 249-255 (2000).

5- H. H. Sayed, A. H. Shamroukh and A. E. Rashad, Acta Pharm., 56, 231-244 (2006).

6- M. M. Youssef, S. F. Mohamed, E. R. Kotb and M. A. Salama, World Jornal of Chemistry, 4 (2), 149-156 (2009).

7- D. M. Smith and G. Tennanat, "Benzimidazoles and Congeneric Tricyclic Compounds", Chemistry of Heterocyclic Compounds, Vol. 40, Part I, Ed. Preston, P. N., John Wiely and Sons, New York, 1981, pp. 360-363.

8 - N. N. Gülerman, H. N. Doğan, S. Rollas, C. Johansson and C. Celik, Il Farmaco, 56, 953-958 (2001).

9- K. S. Atwal, Int. Pat., WO 8906535 (1989), through Chem. Abs., 112, 77212 (1990).
10- S. Sarac, M. Yarim, M. Ertan, S. Boydag and K. Erol, Pharmazie, 53, 91(1998).

11- M. Yaryma, S. Sarac, F. S. Kylic and K. Erol, IL Farmaco, 58, 17 (2003).

12- A. E. Amr, S. S. Maigali and M. M. Abdulla, Monatsh. Chem., 139, 1409-1415 (2008).

13- S. F. Mohamed, E. M. Flefel, A. E. Amr and D. N. Abd El-Shafy, Eur. J. Med. Chem., 45, 1494-1501 (2010).

14- E. Jeaneau-Nicolle, M. Benoit-Guyod, A. Namil and G. Leclerc, ibid., 27, 115-120 (1992)

15- S. M. Sherif, M. M. Youssef, K. M. Mobarak and A. M. Abdel-Fattah, Tetrahedron, 49, 9561-9572 (1993).

16- H. William, "Microbiological Assay, An Introduction to Quantitative Principles and Evaluation" Academic Press, New York (1977).

17- H. Namazi, Y. R. Mirzaei and H. Azamat, J. Het. Chem., 38, 1051-1054 (2001).

18- Y. S. Sadanandam, M. M. Shetty and P. V. Diwan, Eur J. Med. Chem., 27, 87-92 (1992).

19- S. S. Bahekar and D. B. Shinde, Bioorg. Med. Chem. Letters, 14, 1733-1736 (2004). 